\title{
Mechanisms underlying the protective effects of mesenchymal stem cell-based therapy
}

\author{
Xing-Liang Fan ${ }^{1} \cdot$ Yuelin Zhang ${ }^{2} \cdot$ Xin $^{\mathrm{Li}^{2}} \cdot$ Qing-Ling $\mathrm{Fu}^{1,3}$
}

Received: 21 June 2019 / Revised: 2 January 2020 / Accepted: 3 January 2020 / Published online: 21 January 2020

(c) The Author(s) 2020

\begin{abstract}
Mesenchymal stem cells (MSCs) have been extensively investigated for the treatment of various diseases. The therapeutic potential of MSCs is attributed to complex cellular and molecular mechanisms of action including differentiation into multiple cell lineages and regulation of immune responses via immunomodulation. The plasticity of MSCs in immunomodulation allow these cells to exert different immune effects depending on different diseases. Understanding the biology of MSCs and their role in treatment is critical to determine their potential for various therapeutic applications and for the development of MSC-based regenerative medicine. This review summarizes the recent progress of particular mechanisms underlying the tissue regenerative properties and immunomodulatory effects of MSCs. We focused on discussing the functional roles of paracrine activities, direct cell-cell contact, mitochondrial transfer, and extracellular vesicles related to MSC-mediated effects on immune cell responses, cell survival, and regeneration. This will provide an overview of the current research on the rapid development of MSC-based therapies.
\end{abstract}

Keywords Regenerative potential - Integration of MSCs - Immunomodulation - Soluble factors - Cell-cell contact · Mitochondrial transfer $\cdot$ Extracellular vesicles

\begin{tabular}{ll}
\multicolumn{2}{l}{ Abbreviations } \\
AHR & Airway hyper-responsiveness \\
Alix & ALG-2-interacting protein X \\
Ang-1 & Angiopoietin-1 \\
ASCs & Adipose-derived stem cells \\
BAX & BCL-2-associated X protein \\
BCL-2 & B-cell lymphoma 2 \\
CASP3 & Caspase 3 \\
CX43 & Connexin 43 \\
CXCR4 & Chemokine receptor type 4 \\
DC & Dendritic cell
\end{tabular}

Qing-Ling Fu

fuqingl@mail.sysu.edu.cn

1 Otorhinolaryngology Hospital, The First Affiliated Hospital, Sun Yat-Sen University, 58 Zhongshan Road II, Guangzhou 510080, People's Republic of China

2 Department of Emergency, Guangdong Provincial People's Hospital, Guangdong Academy of Medical Sciences, 106 Zhongshan Road II, Guangzhou 510080, People's Republic of China

3 Key Laboratory for Stem Cells and Tissue Engineering, Ministry of Education, Sun Yat-Sen University, Guangzhou, Guangdong, People's Republic of China

$\begin{array}{ll}\text { ER } & \text { Endoplasmic reticulum } \\ \text { ERBB4 } & \text { Erb-B2 receptor tyrosine kinase } 4 \\ \text { EVs } & \text { Extracellular vesicles } \\ \text { FAK } & \text { Focal adhesion kinase } \\ \text { FGF } & \text { Fibroblast growth factor } \\ \text { GM-CSF } & \text { Granulocyte-macrophage colony-stimulating } \\ & \text { factor } \\ \text { GDNF } & \text { Glial-derived neurotrophic factor } \\ \text { GvHD } & \text { Graft-versus-host disease } \\ \text { hESCs } & \text { Human embryonic stem cells } \\ \text { HGF } & \text { Hepatocyte growth factor } \\ \text { HLA } & \text { Human leukocyte antigen } \\ \text { HLA-G5 } & \text { Human leukocyte antigen class I molecule } \\ \text { HO-1 } & \text { G5 } \\ \text { Hsp } & \text { Heme oxygenase-1 } \\ \text { ICAM } & \text { Intercellular adhesion molecules } \\ \text { IDO } & \text { Inducible indoleamine 2,3-dioxygenase } \\ \text { IFN } & \text { Interferon } \\ \text { IGF-I } & \text { Insulin-like growth factor-I } \\ \text { IGF-1R } & \text { Insulin-like growth factor 1 receptor } \\ \text { IL } & \text { Interleukin } \\ \text { ILCs } & \text { Innate lymphoid cells } \\ \text { iNOS } & \text { Inducible nitric oxide synthase } \\ & \end{array}$




$\begin{array}{ll}\text { iPSCs } & \text { Induced pluripotent stem cells } \\ \text { ISCT } & \text { International Society of Cell Therapy } \\ \text { LIF } & \text { Leukemia inhibitory factor } \\ \text { lncRNAs } & \text { Long non-coding RNAs } \\ \text { LPS } & \text { Lipopolysaccharide } \\ \text { MAPK } & \text { Mitogen-activated protein kinase } \\ \text { MCP-1 } & \text { Monocyte chemotactic protein 1 } \\ \text { Mecp2 } & \text { Methyl CpG binding protein 2 } \\ \text { Miro1 } & \text { Mitochondrial Rho-GTPase 1 } \\ \text { miRNA } & \text { MicroRNA } \\ \text { MSCs } & \text { Mesenchymal stem cells } \\ \text { MYD88 } & \text { Myeloid differentiation primary response } \\ & \text { gene } 88 \\ \text { NK } & \text { Natural killer } \\ \text { NO } & \text { Nitric oxide } \\ \text { Nrf2 } & \text { Nuclear factor-erythroid 2 p45-related factor } \\ & 2 \\ \text { PBMCs } & \text { Peripheral blood mononuclear cells } \\ \text { PD-1 } & \text { Programmed death-1 } \\ \text { PD-L1 } & \text { Programmed death-ligand 1 } \\ \text { PGE2 } & \text { Prostaglandin E2 } \\ \text { PGF } & \text { Placental growth factor } \\ \text { PI3K/AKT } & \text { Phosphoinositide-3-kinase and Akt } \\ \text { RA } & \text { Rheumatoid arthritis } \\ \text { ROS } & \text { Reactive oxygen species } \\ \text { SDF-1 } & \text { Stromal cell-derived factor 1 } \\ \text { Sema3A } & \text { Semaphorin-3A } \\ \text { SLE } & \text { Systemic lupus erythematosus } \\ \text { STC1 } & \text { Stanniocalcin-1 } \\ \text { TGF- } \beta & \text { Transforming growth factor- } \beta \\ \text { Th } & \text { T-helper } \\ \text { TLR } & \text { Toll-like receptor } \\ \text { TNF } & \text { Tumour necrosis factor } \\ \text { TNTs } & \text { Tunnelling nanotubes } \\ \text { Tr1 } & \text { Type 1 Treg } \\ \text { Tregs } & \text { Regulatory T cells } \\ \text { TSG } & \text { TNFo-stimulated gene protein } \\ \text { UCP } & \text { Uncoupling protein } \\ \text { VCAM } & \text { Vascular cell adhesion protein } \\ \text { VEGF } & \text { Vascular endothelial growth factor } \\ \text { XCL1 } & \text { Chemokine (C motif) ligand } \\ & \end{array}$

\section{Introduction}

Mesenchymal stem cells (MSCs), alternatively referred to as mesenchymal stromal cells, have been extensively investigated since their discovery in the bone marrow by Alexander Friedenstein and colleagues in the late 1960s [1, 2]. MSCs can migrate to injured sites, engraft, and differentiate into end-stage functional cells, thus repairing the injured tissue $[3,4]$. More importantly, MSCs have also shown promising therapeutic effects due to their ability to modulate multiple immune cell types of both the innate and adaptive immune systems. MSCs can promote neovascularization, increase angiogenesis, enhance cell viability and/or proliferation, inhibit cell death, and modulate immune responses via paracrine and cell-cell contact effects as well as through extracellular vesicles [5, 6]. Recently, over 900 clinical trials worldwide have used MSCs to treat various diseases (www. clinicaltrials.gov), including bone/cartilage repair, diabetes, cardiovascular diseases, immune-related, and neurological disorders. MSCs are attractive candidates for treating various diseases because they can travel to injured sites, differentiate into multiple cell types, and regulate immunomodulation [7]. In particular, the role of homing in MSC-based therapies remains doubtful. Interestingly, despite some encouraging results from animal studies, some clinical trials have also shown no therapeutic efficacy of MSCs. Therefore, understanding the biology of MSCs and their role in treatment will be critical to determine their potential for various therapeutic applications. This review summarizes the mechanisms underlying the protective effects of MSCs and provides an overview of the recent developments in MSC-based therapy.

\section{MSC identity}

MSCs are classically defined as plastic-adherent, expanding, non-hematopoietic cells that can differentiate into osteoblasts (bone cells), adipocytes (fat cells), chondroblasts (cartilage cells) and myocytes (skeletal muscle cells) in vitro [8-10]. They express the cluster of differentiation (CD) surface markers including CD90, CD105, and CD73, but do not express CD11b, CD14, CD19, CD34, CD45 and human leukocyte antigen (HLA)-DR according to the International Society of Cell Therapy (ISCT) criteria [8, 9, 11]. However, this set of cell surface markers is not always applicable when identifying MSCs as pericytes and defining the cell markers. MSCs isolated from different tissues have different surface antigen molecules because these surface markers are influenced by many factors. The surface markers of MSCs isolated from the lung are distinct from those of the MSCs derived from the bone marrow [12]. Additional/alternative markers are being identified and confirmed for some specific sources of MSCs. For instance, CD146 is essential for MSC vigour and self-renewal as the dividing ability of MSCs is weakened or eliminated when $C D 146$ is downregulated or silenced [13]. CD49d is detected in adipose-derived MSCs but not in BM-MSCs [14]. To date, markers for identification of MSCs are under investigation. There needs to be a more critical take on a field that has deviated from careful science. 


\section{Sources of MSCs}

Although bone marrow is the conventional source of MSCs, MSCs or MSC-like cells can be isolated from almost any tissue of the human body. MSC-like cells have been isolated from a variety of foetal, neonatal, and adult tissues including adipose tissue, amniotic fluid, brain, compact bone, dermis, dental pulp, gingiva, foetal liver and lung, human islets, placenta, skeletal muscle, synovium, umbilical cord, peripheral blood and so on (Fig. 1) [14-24]. It is considered that MSCs refer to cells derived from the bone marrow, but not necessarily those from other sites such as adipose tissue, which are often termed as adipose-derived stem cells (ASCs). However, MSCs derived from different origins have different characteristics and differentiation potential [25, 26]. Moreover, MSCs from different sources display significant differences in the levels of several paracrine factors [27]. Currently, the most frequently reported sources of MSCs utilized in clinical trials are the bone marrow, adipose tissue, and umbilical cord. This is partially due to the accessibility, ease of isolation, and MSC-based repair efficacy. The characteristics and differentiation potential of the most commonly investigated MSCs derived from different tissues have been summarized in Table 1 .

Although MSCs can hypothetically be obtained from almost any tissue within the human body, the MSC surface markers, quality and isolated numbers are restricted by various donor characteristics. There are also practical limitations concerning the difficulty and invasiveness of the procurement process [25]. To select an adequate cell source, the practitioner must consider both advantages and disadvantages of procuring MSCs with regard to the difficulty and potential adverse effects of harvesting donor the cells. For instance, BM-MSCs have shown confirmed safety and effectiveness in multiple clinical trials, but their yields and differentiation potential are dependent on the donor characteristics (e.g., age). Moreover, isolation of cells from the bone marrow is often painful and carries the risk of infection. As adipose tissue is accessible and abundant, this source results in the isolation of stem cells that is 500 times more than the ones obtained from the bone marrow. Adipose tissuederived MSCs have stronger immunosuppressive effects but have inferior osteogenic and chondrogenic potential as compared to the potential seen in BM-MSCs. The frequency of
Fig. 1 MSCs can be isolated from a variety of foetal, neonatal, and adult tissues, and can differentiate into different cell types. $C D$ cluster of differentiation, ESCs embryonic stem cells, iPSCs induced pluripotent stem cells, MSCs mesenchymal stem cells

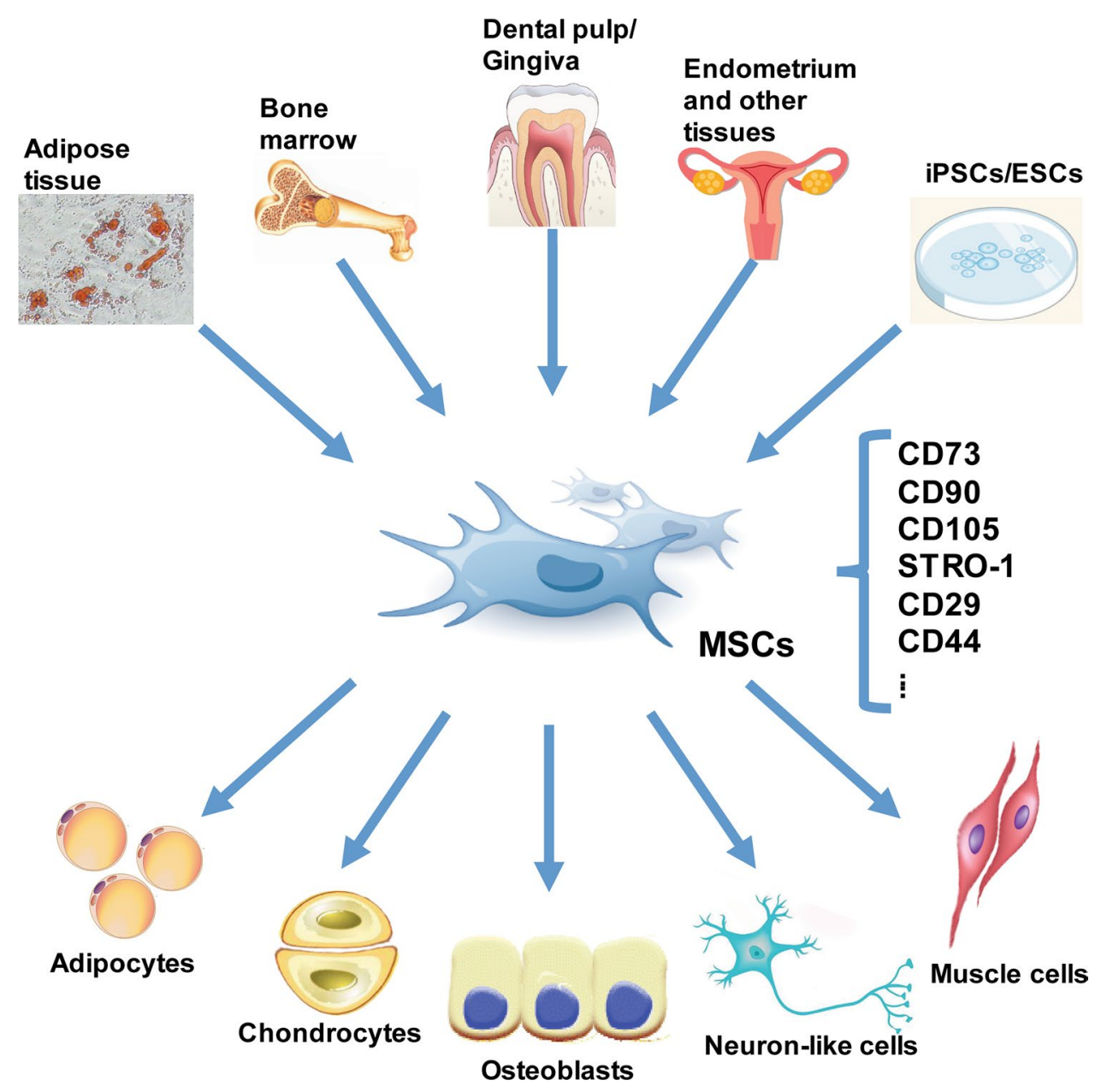


Table 1 Characteristics and differentiation potential of the common different tissue-derived MSCs

\begin{tabular}{|c|c|c|c|}
\hline Source tissue & Characteristics & Differentiation potential & References \\
\hline Adipose tissue & $\begin{array}{l}\text { CD73, CD90, CD29, CD44, CD71, CD105, CD13, } \\
\text { CD166, STRO-1 }\end{array}$ & Adipocyte, chondrocyte, osteoblast & {$[29-31]$} \\
\hline Amniotic fluid & CD44, CD90, CD105, CD13, CD29, CD71, CD120a & $\begin{array}{l}\text { Adipocyte, cardiomyocyte-like cell, chondrocyte, } \\
\text { osteoblast }\end{array}$ & {$[32,33]$} \\
\hline Bone marrow & CD73, CD90, CD105, STRO-1 & $\begin{array}{l}\text { Adipocyte, chondrocyte, osteoblast, tenocyte, vascular } \\
\text { smooth muscle cell }\end{array}$ & {$[34-37]$} \\
\hline Dental pulp & CD29, CD44, CD90, CD105 & $\begin{array}{l}\text { Adipocyte, chondrocyte, osteoblast, neuron-like cell, } \\
\text { odontoblast, myogenic lineages }\end{array}$ & {$[38-41]$} \\
\hline Endometrium & CD29, CD90, CD73, CD105 & Adipocyte, chondrocyte, osteoblast & {$[42,43]$} \\
\hline Peripheral blood & CD44, CD90, CD105, HLA-ABC & Adipocyte, osteoblast, fibroblast & [44] \\
\hline Placenta & CD29, CD73, CD90, CD105 & $\begin{array}{l}\text { Adipocyte, chondrocyte, osteoblast, myotubular cell, } \\
\text { pancreatic progenitor cell, neuron-like cell, retinal } \\
\text { cell }\end{array}$ & {$[45,46]$} \\
\hline Synovium & CD44, CD90, CD105, CD147, STRO-1 & $\begin{array}{l}\text { Adipocyte, chondrocyte, osteoblast, skeletal muscle } \\
\text { cell }\end{array}$ & {$[29,47,48]$} \\
\hline Skin & $\begin{array}{l}\text { CD44, CD73, CD90, CD105, CD166, SSEA-4, } \\
\text { Vimentin }\end{array}$ & $\begin{array}{l}\text { Adipocyte, chondrocyte, osteoblast, neuron-like cell, } \\
\text { pancreatic cell, endothelial cell }\end{array}$ & {$[49-51]$} \\
\hline Umbilical cord & CD29, CD44, CD73, CD90, CD105 & $\begin{array}{l}\text { Adipocyte, chondrocyte, osteoblast, skeletal mus- } \\
\text { cle cell, endothelial cell, cardiomyocyte-like cell, } \\
\text { neuron-like cell }\end{array}$ & {$[52,53]$} \\
\hline
\end{tabular}

colony-forming cells from dental pulp is high compared to those from bone marrow, and the source materials are easily accessible as dental surgeries are fairly common. However, ectomesenchymal and periodontal tissues can affect the properties of dental pulp-derived MSCs [28]. MSCs derived from birth-related tissues (amnion, placenta and umbilical cord) demonstrate higher expansion and engraftment capacity, but these cells are not as useful as those from bone marrow or blood in terms of osteogenesis [25]. Obtaining MSCs from different tissues will demonstrate various characteristics that may differ due to the tissue source, health condition, and age of the donor. Thus, researchers have begun to differentiate MSCs from pluripotent stem cells, to circumvent the drawbacks of tissue-derived MSCs.

MSCs can be derived from pluripotent stem cells including human embryonic stem cells (hESCs) and induced pluripotent stem cells (iPSCs) $[54,55]$. Despite no direct sequencing comparisons between pluripotent stem cellderived MSCs and BM-MSCs, iPSC-MSCs indeed express typical MSC surface markers and undergo adipogenesis, osteogenesis, and chondrogenesis similar to that observed in adult BM-MSCs [55-57]. The functional characteristics of iPSC-MSCs have made the cells usable for tissue engineering and cellular therapeutics. More importantly, MSCs derived from pluripotent stem cells display a higher proliferative capacity and telomerase activity. These cells have a higher proliferative capacity (more than 50 passages), and lower cell senescence than that observed in BM-MSCs $[55,57,58]$. We also observed no teratogenic effects of iPSC-MSCs in animal studies, implying the safety of using
iPSC-MSCs [55]. Furthermore, iPSC-MSCs from aged individuals were reported acquire a rejuvenation signature, which circumvents the ageing-associated drawbacks [59]. A very large number of functional MSCs can be clonally generated from a single-cell level, which maintains the homogeneity and functional quality of MSCs.

Moreover, compared with BM-MSCs, iPSC-MSCs are more insensitive to pro-inflammatory interferon (IFN)- $\gamma$ induced HLA-II expression, exhibiting stronger immune privilege, superior survival rates, and improved engraftment after transplantation. This means that pluripotent stem cell-derived MSCs have a stronger advantage in allogeneic transplantation [58]. Recently, the use of adult tissues, especially bone marrow, as a source of MSCs has decreased [60]. However, pluripotent stem cell-derived MSC-based therapy is in the early investigational stage and is not ready for clinical application as many challenges remain to be overcome. For instance, there are ethical issues in hESC application. Will the original tissue/cell of iPSCs ultimately affect the function and effect of MSCs in different diseases? Will iPSC reprogramming cause genome instability? Genome sequencing should thus be carried out to verify the correctness of each base in iPSCs. Direct comparisons using advanced techniques such as RNAseq indicating that pluripotent stem cell-derived MSCs are similar to MSCs derived from adult tissues will be favourable. The reprogramming method may also affect the function of MSCs, but existing reprogramming methods such as those using small molecular compounds can avoid the hidden dangers posed by virus-mediated reprogramming. 


\section{MSC functions}

In addition to cells of the mesodermal lineage (i.e., adipocytes, chondrocytes, osteoblasts and skeletal myocytes), MSCs also can differentiate into cells of ectodermal origin and endodermal origin, such as hepatocytes and neuronlike cells [61, 62]. Significant progress has been achieved in tissue regeneration using MSCs in de-cellularized or synthetic scaffolds [63]. However, the encouraging regenerative potential of MSCs is mainly validated by in vitro functional assays. Upon allogeneic transplantation, MSCs have shown protective effects in a variety of injured models including damaged bone, cartilage [64], hepatic [65], myocardial [66], and neural tissues [67]. However, the therapeutic effects of MSCs are not attributed to poor cell retention [68].

It is becoming increasingly evident that the therapeutic effects of MSCs are largely attributed to the immunomodulatory function. MSCs exert immunomodulatory and antiinflammatory effects by regulating lymphocytes associated with both innate and adaptive immune systems [68]. It is well documented that MSCs regulate the immune response in many diseases [69]. Accumulating evidences have demonstrated that MSCs can regulate $\mathrm{T}$ cell proliferation, function, balance T-helper (Th) 1 and Th2 activity [69, 70], upregulate the functions of regulatory T cells (Tregs) [71], suppress B cell functions [72, 73], inhibit natural killer (NK) cell proliferation and function [74], and prevent dendritic cell (DC) maturation and activation $[6,57,62]$. MSCs can also stimulate proliferation and cytokine secretion in innate lymphoid cells (ILCs), a new family of lymphocyte-like cells, which play an important role in innate defences against pathogens $[75,76]$. MSCs can regulate their immunomodulatory functions according to the micro-environmental inflammatory conditions. The plasticity of MSCs in immunomodulation is affected by the type and intensity of inflammatory stimuli conferred on MSCs. For instance, MSCs can suppress the polarization of Th1 and Th17, and promote Th2 polarization in graft-versus-host disease (GvHD) [77]. Meanwhile, MSCs can also inhibit Th2-dominant allergy by inhibiting IL-4 and IL-13 production [7]. Furthermore, MSCs promote the responses of lymphocytes in quiescent-state peripheral blood mononuclear cells (PBMCs) from patients with allergic rhinitis [70]. MSCs exert immunosuppressive effects or contribute to the fibrotic process under acute or chronic inflammatory conditions, respectively $[62,78]$. Their immunomodulatory characteristics thus make MSCs a flexible and feasible strategy for treating various diseases.

The function of MSCs is known to decline with age, a process that may be implicated in the loss of tissue homeostasis leading to organ failure and aging-related diseases [79]. The proliferative and functional activity of MSCs is destined to decline during the process of senescence. The osteogenic activity of senescent MSCs deteriorates as a function of increasing lifespan, whereas the adipogenic differentiation potential of MSCs remains unchanged or is even enhanced [80]. For osteogenic induction, early passages MSCs or strategies to prevent senescence must be considered to yield longer osteogenesis and better quality. Furthermore, the immunomodulatory functions of MSCs are also reported to be compromised due to increased reactive oxygen species and oxidative stress in aged cells [81]. Therefore, MSC senescence may have a major impact on their therapeutic function. This calls for research on senescence and the development of efficient means to rejuvenate MSCs. Recently, several strategies have been explored to rejuvenate senescent MSCs, and subsequently enhance their functions. Overexpression of neuron-derived neurotrophic factor was found to rejuvenate aged BM-MSCs and improve their function in repairing the aged heart after ischemia [82]. microRNA (miR)-10a rejuvenated aged BMMSCs and enhanced the cardiacprotection following infarction in mice via increased paracrine effects [83]. Furthermore, overexpressing FGF 21 in MSCs may delay their senescence during passaging in vitro [84]. Indeed, rejuvenating MSCs isolated from aged individuals or patients to enhance their functions is of great importance.

\section{Therapeutic properties of MSCs}

Their regenerative and immunomodulatory properties enable MSCs as a novel strategy for treating a wide variety of diseases including autoimmune diseases [85, 86], bone and cartilage diseases [3, 87], cardiovascular diseases [88, 89], inflammatory airway disorders [6, 90], liver diseases [91, 92], muscle diseases [93], neurodegenerative diseases [94, 95], spinal cord injuries [96] and so on. The osteogenic differentiation potential of MSCs makes them successful in treating and managing bone fractures [97]. The ability of MSCs to modulate immune responses is considered as a safe and feasible strategy to treat Crohn's disease [98], systemic lupus erythematosus (SLE) [99, 100], rheumatoid arthritis (RA) [101], GvHD [102], Type I diabetes [103] and so on. MSCs also prevent allergic airway inflammation and reduce the symptoms of severe asthma [104-108]. Administration of MSCs functionally attenuates airway hyper-responsiveness (AHR), inflammatory cell infiltration, and mucus production in animal models [104, 109-113]. Upon transplantation, MSCs have shown various favourable effects in treating neurodegenerative diseases via enhanced neurogenesis, inflammation modulation, and abnormal protein aggregate clearance [94]. Thus, MSCs have shown promising results in the clinical application of stem cell therapy. 


\section{Clinical application of MSCs}

The safety, feasibility and efficacy of MSC therapy for different diseases has been extensively investigated over the past decades. The recent development of MSC-based products for treating diseases provides a bridgehead from which MSCs can be implemented in clinical utility. Considering both the ongoing and completed clinical trials, MSC-based treatment appears to maintain the promise of safety and demonstrates that MSC administration is feasible. However, despite MSC application in the early stage of clinical trials, much work is needed before MSCs can pass from the bench to the bed-side [114]. Table 2 lists some of the clinical trials with outcomes involving the administration of MSCs. Some studies have shown beneficial effects, whereas some studies have shown no effects of MSCs. These mixed and contradictory results in clinical trials hamper the application of MSCs. Among 178 registered clinical trials using umbilical cord-derived MSCs between years 2007-2017, only 16\% had statuscompleted by 27 th October, 2018. During the same time, a total of 98 clinical studies were published. Although $74 \%$ of the publications reported some promising results, only $18 \%$ of the publications showed that this treatment was safe [115]. Although the safety of MSC transplantation was confirmed, less than $40 \%$ of the studies and clinical trials with available and published results showed

Table 2 Summary of some clinical trials with outcomes involving MSC administration

\begin{tabular}{|c|c|c|c|c|}
\hline Disease & $\begin{array}{l}\text { MSC S } \\
\text { ource }\end{array}$ & Dosage and delivery route & Efficacy & NCT number/reference \\
\hline \multirow[t]{3}{*}{$\begin{array}{l}\text { Amyotrophic lateral scle- } \\
\text { rosis }\end{array}$} & $\begin{array}{l}\text { Autologous bone marrow- } \\
\text { derived MSCs }\end{array}$ & $\begin{array}{l}1 \times 10^{6} \text { cells } / \mathrm{kg} \text {, via } 2 \\
\text { repeated intrathecal injec- } \\
\text { tions }\end{array}$ & Delayed disease progression & NCT01363401 \\
\hline & $\begin{array}{l}\text { Autologous adipose-derived } \\
\text { MSCs }\end{array}$ & $\begin{array}{l}1 \times 10^{7}-1 \times 10^{8} \text { cells, via } \\
\text { intrathecal injection }\end{array}$ & No effect & NCT01609283 \\
\hline & $\begin{array}{l}\text { Autologous bone marrow- } \\
\text { derived MSCs }\end{array}$ & $\begin{array}{l}15 \times 10^{6} \text { cells, via intrathe- } \\
\text { cal injection }\end{array}$ & Variable effects & NCT02881489 \\
\hline \multirow[t]{2}{*}{ Type 2 diabetes mellitus } & $\begin{array}{l}\text { Autologous bone marrow- } \\
\text { derived MSCs }\end{array}$ & $\begin{array}{l}\text { Injected into the gastroduo- } \\
\text { denal artery/ pancreati- } \\
\text { coduodenal artery }\end{array}$ & $\begin{array}{l}\text { Improvement in daily } \\
\text { insulin requirements. } \\
\text { Nausea and vomiting were } \\
\text { recognized }\end{array}$ & {$[119,120]$} \\
\hline & Placental-derived MSCs & $\begin{array}{l}1.35 \times 10^{6} \text { cells } / \mathrm{kg}, 3 \\
\text { intravenous infusions at } \\
1 \text {-month intervals }\end{array}$ & $\begin{array}{l}\text { Improvements in C-pep- } \\
\text { tides, HbA1c levels, and } \\
\text { insulin dosages. Nausea } \\
\text { and vomiting were rec- } \\
\text { ognized }\end{array}$ & {$[121]$} \\
\hline \multirow[t]{4}{*}{ Spinal cord injury } & $\begin{array}{l}\text { Autologous bone marrow- } \\
\text { derived MSCs }\end{array}$ & $\begin{array}{l}8 \times 10^{6} \text { cells, via intrathecal } \\
\text { administration }\end{array}$ & $\begin{array}{l}\text { Improvement in ASIA } \\
\text { score, EMG, and SEP; } \\
\text { improvement in MRI } \\
\text { imaging }\end{array}$ & {$[122]$} \\
\hline & $\begin{array}{l}\text { Autologous bone marrow- } \\
\text { derived MSCs }\end{array}$ & $\begin{array}{l}89.7 \times 10^{6} \text { cells, via intra- } \\
\text { arterial or intravenous } \\
\text { administration }\end{array}$ & No significant improvement & [123] \\
\hline & $\begin{array}{l}\text { Autologous bone marrow- } \\
\text { derived MSCs }\end{array}$ & $\begin{array}{l}1 \times 10^{6} \text { cells, via intrathecal } \\
\text { administration }\end{array}$ & $\begin{array}{l}\text { Variable patterns of recov- } \\
\text { ery }\end{array}$ & [124] \\
\hline & $\begin{array}{l}\text { Autologous bone marrow- } \\
\text { derived MSCs }\end{array}$ & $\begin{array}{l}7 \times 10^{5} \text { to } 1.2 \times 10^{6} \text { cells, via } \\
\text { intrathecal administration }\end{array}$ & $\begin{array}{l}\text { Positive trend, but not statis- } \\
\text { tically significant }\end{array}$ & {$[125]$} \\
\hline \multirow[t]{3}{*}{ Stroke } & $\begin{array}{l}\text { Autologous bone marrow- } \\
\text { derived MSCs }\end{array}$ & $\begin{array}{l}50-60 \times 10^{6} \text { cells, via intra- } \\
\text { venous administration }\end{array}$ & $\begin{array}{l}\text { No improvement in all clini- } \\
\text { cal scores }\end{array}$ & [126] \\
\hline & $\begin{array}{l}\text { Autologous bone marrow- } \\
\text { derived MSCs }\end{array}$ & $\begin{array}{l}4.57 \times 10^{7} \text { MSCs per } \\
\text { intravenous infusion were } \\
\text { administered amounting } \\
\text { to } 8.54 \times 10^{5} \text { per kilogram } \\
\text { body weight at two occa- } \\
\text { sions ( } 4 \text { weeks apart) }\end{array}$ & $\begin{array}{l}\text { Improvements in motor } \\
\text { disability and cognitive } \\
\text { impairment }\end{array}$ & {$[127]$} \\
\hline & $\begin{array}{l}\text { Umbilical cord-derived } \\
\text { MSCs }\end{array}$ & $\begin{array}{l}5 \times 10^{6}-1 \times 10^{7} \text { cells, via } \\
\text { intraventricular adminis- } \\
\text { tration }\end{array}$ & Safe and feasible & [128] \\
\hline
\end{tabular}


positive improvements in the use of MSCs for patients with amyotrophic lateral sclerosis [116]. Administration of MSCs in clinical trials exhibited beneficial effects on diabetes. However, no significant therapeutic effect was observed and the clinical measures were rapidly restored to the baseline [117]. Compared to adult MSCs, clinical trials using iPSC-MSCs have just begun. The first clinical trial using iPSC-MSCs is now underway to test the clinical efficacy in human patients with steroid-resistant acute GvHD (ClinicalTrials.gov Identifier: NCT02923375). The utilized iPSC-MSCs have been found to be safe and well tolerated in the first cohort (of eight GvHD patients) enrolled in a phase I trial (https://www.cynata.com/graft versushostdisease) [118].

The contradictory results in MSC clinical application may be caused by the heterogeneity of MSCs, which is the main problem that restricts the therapeutic benefit of MSCs. The heterogeneity of MSCs is influenced by the key parameters of MSCs including donor origin, tissue origin, passage number, expansion protocol, delivery dosage, route and so on. Additionally, multiple factors including the culture condition, the exact diseases intended to be targeted, and the local conditions of administration may also affect the immunomodulatory function of MSCs. These factors directly affect the outcome of MSC-based application. More importantly, many clinical trials have similar limitations in examining the effects of MSCs, including small size, lack of control arms in some cases, and inconsistent methods of isolating and using MSCs. Homogeneity and quality control are the most critical issues for the clinical application of MSCs. Larger studies with more randomized, blinded, strictly-regulated trials and longer follow-up times that show the beneficial effects of MSCs are also needed. This implies that the efforts of researchers and clinicians will focus on revealing the mechanisms that affect the effects of MSCs.

\section{Mechanisms underlying MSC-based therapy}

The therapeutic potentials of MSCs are mainly attributed to two aspects: first, replacement of the damaged tissue by differentiating into various cell lineages, and the second, regulation of immune responses by immunomodulatory function. Rather than long-term engraftment and differentiation of the integrated MSCs, a growing body of studies has shown that the protective effects of MSCs for damaged and diseased tissues are attributed to alternative immunomodulatory modes. The major mechanism underlying MSC-based therapy is the paracrine function, which secretes a variety of soluble factors to exert immunomodulatory, angiogenic, antiapoptotic and antioxidative effects [129, 130]. Cell-cell contact enables MSCs to modulate their immunosuppressive effects and promote cell viability. MSCs can transfer mitochondria to injured cells via tunnelling nanotubes (TNT) $[131,132]$. Furthermore, MSCs reduce inflammation and increase cell proliferation during tissue repair via releasing exosomes that contain reparative peptides/proteins, mRNA, and microRNA (miRNA) (Fig. 2) $[133,134]$.

\section{Integration of differentiated MSCs}

MSCs have remarkable differentiation potential. After transplantation, differentiated MSCs can successfully integrate into the diseased host tissue. Integration of stem cells is necessary for the improvement of endogenous tissue repair, in order to replace the dead or damaged cells. MSCs and their progenitors can differentiate into chondrocytes and undergo chondrogenesis [135-137]. MSCs can differentiate into cardiomyocytelike cells, integrate into host tissue, and enhance resident cell activity [138]. With the help of nano-biomaterials, MSCs have achieved better differentiation and functional integration for repairing myocardial infarction repair [139-141]. Transplanted MSCs can integrate into partially hepatectomized or toxicinjured liver for hepatic regeneration [142, 143]. Integration of MSCs has also demonstrated promising results in the treatment of neurodegenerative diseases. MSCs can integrate into the parenchyma of both the brain and the spinal cord. Intraparenchymal delivered MSCs were proven to be safe, and significantly delayed the loss of motor neurons [144]. Tzameret et al. found that intravitreally injected MSCs ameliorate retinal degeneration by integrating into the neural layers of the damaged retina [145]. Moreover, analysis of tissues after MSC transplantation revealed cell fusion between transplanted MSCs and cells of the recipient, albeit at a low frequency. MSC fusion was observed in many organs such as the brain, retina, the liver, muscles, and the gut where they participated in the reestablishment of tissue function [146]. The exact biological implication of MSC fusion is unclear. However, it is worth mentioning that cell fusion between MSCs and cancer cells enhances metastatic capacity and the characteristics of cancer stem cells by undergoing epithelial-mesenchymal transition, which is considered a key cell event in the process of tumour metastasis and invasion [147, 148]. Overall, the engraftment and differentiation efficacy of MSCs post-transplantation is very low which heavily limits their therapeutic effects. The differentiation potential of MSCs largely depends on donor age, tissue origin, cell passage numbers, cell densities, duration of cell culture and so on. Therefore, further investigation is needed to reveal the mechanisms of regulatory pathways and improve differentiation efficacy. 


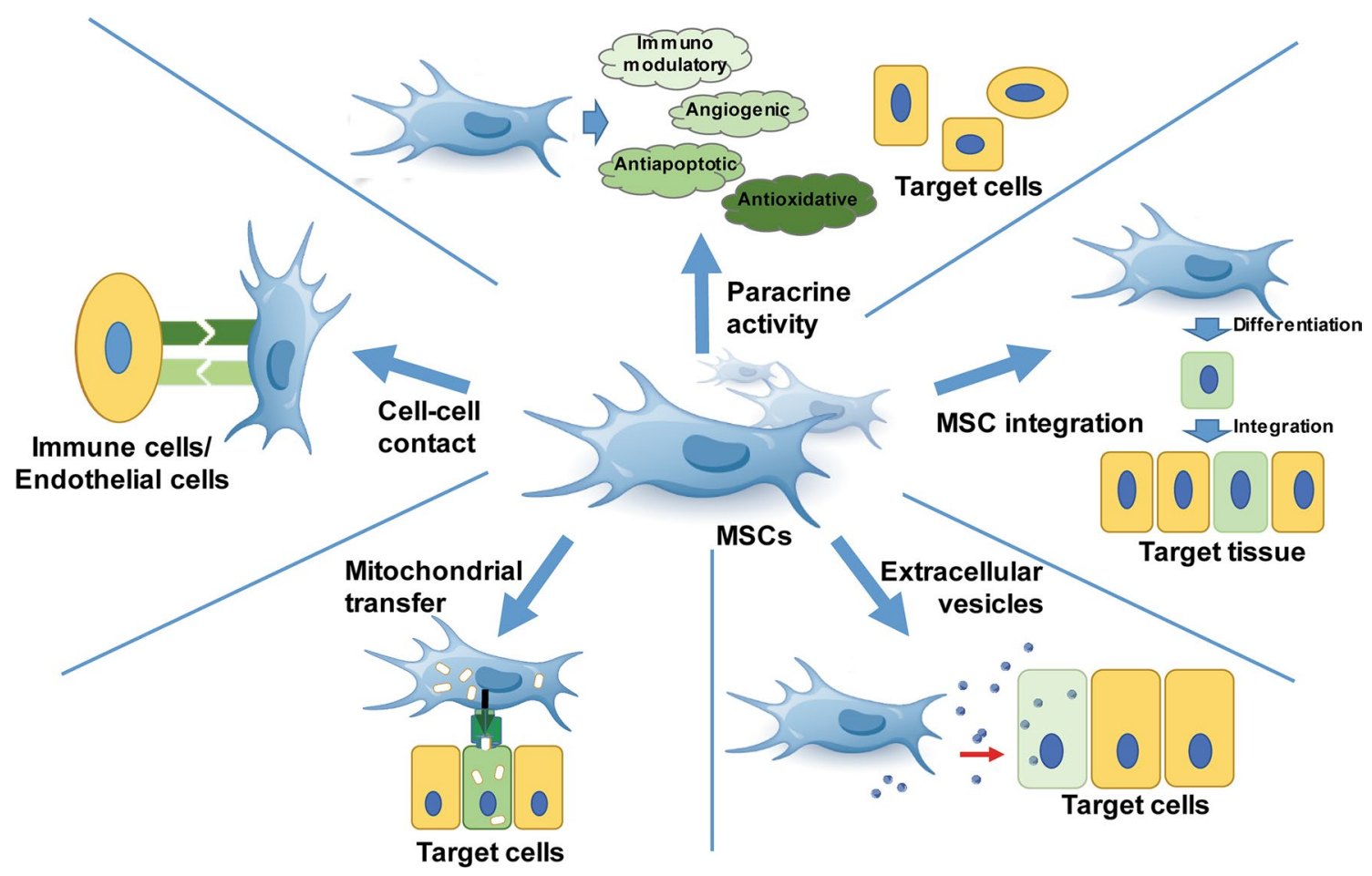

Fig. 2 Mechanisms underlying MSC-based therapy. MSCs rescue and/or repair injured cells via differentiation into replacement cell types and by modulating immune responses. The immunomodulatory modes of MSCs include paracrine activity, cell-cell contact and inter-

\section{Soluble factors}

\section{Immunomodulatory factors}

The low immunogenicity makes MSCs eligible for allogeneic transplantation. MSCs can inhibit $\mathrm{CD}^{+}{ }^{+}$cell, $\mathrm{CD} 8^{+}$ $\mathrm{T}$ cell, and NK cell proliferation and DC maturation, suppress plasma cell immunoglobulin production, and stimulate Treg proliferation by secreting transforming growth factor- $\beta$ (TGF- $\beta$ ), hepatocyte growth factor (HGF), inducible indoleamine 2,3-dioxygenase (IDO), human leukocyte antigen class I molecule (HLA)-G5, prostaglandin E2 (PGE2), interleukin (IL)-6, IL-10, TNF $\alpha$-stimulated gene protein (TSG)-6 and so on. Bartholomew A. et al. showed that MSCs suppress lymphocyte proliferation, alter lymphocyte reactivity to allogeneic target cells, and prolong skin graft survival following intravenous administration in MHCmismatched baboons [149]. Furthermore, Di Nicola et al. demonstrated that soluble factors secreted by MSCs partly contribute to immunomodulatory capacity in a co-culture of MSCs with T-lymphocytes in a Transwell system, which excludes cell-cell contact. TGF- $\beta$ or HGF are involved in the inhibition of $\mathrm{T}$ cell proliferation by the addition of a monoclonal antibody in the system [150]. The secreted TGF- $\beta$ promotes the differentiation of naive $\mathrm{T}$ cells into action, mitochondrial transfer, and release of extracellular vesicles. The mechanisms involved in repair are not equivalent and MSCs can adapt their therapeutic effects according to diverse local microenvironments. MSCs mesenchymal stem cells

Treg cells, thus improving systemic immune tolerance [151]. Furthermore, Zhong et al. demonstrated that the TGF- $\beta 1 /$ Smad signalling pathway is involved in the immunomodulatory effects of MSCs in chronic allergic airway inflammation [152]. MSCs primed with IFN- $\gamma$ will secrete IDO, which subdues the T-cell response to autoantigens and foetal alloantigens [153]. Furthermore, IDO catalyses the conversion of tryptophan to kynurenine, which inhibits T-cell proliferation [154]. Additionally, the primed MSCs secrete programmed death-ligand 1 (PD-L1), which co-inhibits the adaptive immune response in tissue allografts, autoimmune disease and other diseases [155]. MSC-secreted HLA-G5 suppresses $\mathrm{T}$ lymphocytes and $\mathrm{NK}$ function, and induces the expansion of $\mathrm{CD} 4{ }^{+} \mathrm{CD} 25^{\text {high }} \mathrm{FOXP} 3^{+}$Treg cells [71]. MSCs regulate adaptive immune responses by secreting PGE2, which induces DCs to upregulate the anti-inflammatory cytokine IL-10, while reducing the secretion of pro-inflammatory tumour necrosis factor (TNF)- $\alpha$ and IL-12 [156, 157]. This will convert the pro-inflammatory Th1 cells to the anti-inflammatory Th 2 cell phenotype. Meanwhile, naïve T cells differentiate into Treg cells, which further decrease the total number of T helper cells [156]. Moreover, MSCs exert immunomodulatory effects by secreting IL-6, which inhibits lymphocytes apoptosis [158]. In addition, MSC-derived nitric oxide (NO) [159], leukaemia inhibitory factor (LIF) 
[160], galectin-1, and semaphorin-3A [161] inhibit T lymphocyte proliferation. LIF suppresses $\mathrm{T}$ cell proliferation as well as promotes and maintains Tregs [162].

MSC-derived soluble factors also modulate macrophage behaviour. The pro-inflammatory phenotype M1 (classicalactivated macrophage) transits to the anti-inflammation phenotype M2 (alternative-activated macrophage) in the presence of MSCs [163]. Tsyb et al. demonstrated that MSC-derived TSG-6, via the CD44 receptor, ameliorates macrophages to secrete inflammatory factors by inhibiting NF- $\kappa B$ activity. TSG- 6 also inhibits the maturation and function of DCs [164, 165]. Zhang et al. found that galectin-1 from MSCs stimulates the formation of a tolerance immunophenotype on DCs via regulating the MAPK signalling pathway in DCs, thereby inhibiting their function [166]. The immunomodulatory effects of MSC-derived factors have been observed during both the antigen recognition/ presentation stage and $T$ cell activation stage of the immune response. Recent studies have shown that the immunosuppressive potency of MSCs is predominantly mediated by key molecules including Rap1 and IDO1 [167, 168]. Furthermore, novel strategies including hypoxia preconditioning and chemical pre-treatment can significantly enhance the immunosuppressive potency of MSCs [169, 170].

MSCs mediate immune responses via diverse modes of action. MSCs can be either immunosuppressive or immune-enhancing depending on the soluble factor levels in the microenvironment. $\mathrm{Li}$ et al. found that the degree of NO production acts as a switch in MSC-mediated immunomodulation. MSCs tend to promote $\mathrm{T}$ cell proliferation rather than immunosuppression when inducible nitric oxide synthase (iNOS), one of three key enzymes generating NO, is blocked. The level of iNOS/IDO plays a critical role in determining the pathophysiological roles of MSCs [171]. Cuerquis et al. further confirmed that MSCs induce a transient increase in IFN- $\gamma$ and IL-2 synthesis by activating T cells before suppressing T-cell proliferation [172]. Therefore, in addition to MSC isolation protocols, their origins and dosages, the inflammatory state and level of soluble factors in immune diseases must also be considered before MSC intervention.

\section{Angiogenic factors}

It has been proven that the angiogenic (the sprouting of existing vessels) and arteriogenic (the growth of collateral vessels) properties of MSCs contribute to the amelioration of hind limb ischemia, coronary artery disease, and skin wound repair [55, 58, 173-176]. Angiogenesis is a complex multistep process that forms new blood networks, which requires endothelial cell growth and differentiation-associated soluble growth factors such as vascular endothelial growth factor (VEGF) and fibroblast growth factor (FGF) [177].
MSCs secrete VEGF, FGF, HGF, placental growth factor (PGF), monocyte chemotactic protein 1 (MCP-1), stromal cell-derived factor 1 (SDF-1), and angiopoietin-1 (Ang-1) that are critical for vascularization [178-183]. Several studies have reported the potential of increasing capillaries and newly formed vessels following MSC administration both in vitro and in vivo [184-186]. Hung et al. demonstrated that angiogenic factors including IL-6, MCP-1, and VEGF in MSC-conditioned medium inhibit apoptosis, increase survival, and stimulate angiogenesis of endothelial cells under hypoxic challenge [179]. IL-6 promotes angiogenesis and survival of endothelial cells [187]. MCP-1 has been proven as a critical chemoattractant for angiogenesis [188]. VEGF can promote MSC differentiation as well as regulate endothelial cell migration, differentiation and endothelialisation via activation of the mitogen-activated protein kinase (MAPK), phosphoinositide-3-kinase and Akt (PI3K/AKT), Src, and Rac pathways [189]. Overexpression of Erb-B2 receptor tyrosine kinase 4 (ERBB4) can rejuvenate aged MSCs and stimulate angiogenesis by regulating the PI3K/ AKT and the MAPK/ERK pathways, leading to increased therapeutic effects for myocardial infarction [190]. MSCs promote angiogenesis via the SDF-1/C-X-C chemokine receptor type 4 (CXCR4) axis [191]. Moreover, Dong et al. found that myocardial CXCR4 is required for MSC-derived SDF-1, meditating repair in acute myocardial infarction [192]. MSC-derived angiogenic factors such as SDF-1 and HGF promote local angiogenesis [193, 194]. SDF-1 stimulates endothelial cell proliferation and capillary tube formation, whereas HGF promotes tyrosine phosphorylation in endothelial cells and smooth muscle cells via the c-Met receptor [195, 196]. Further, MSC-derived angiogenic soluble factors improve angiogenesis and restore blood supply in ischemic areas. However, it is unclear whether MSC-derived soluble factors account for the dominant mechanisms of action. The importance of hibernating cells and susceptible cells in the local region should also be considered [129, 197].

\section{Anti-apoptotic factors}

The multiple roles of apoptosis in regulating various physiological and pathological functions implicate its significance in disease treatment [198]. Moreover, MSCs can synthesise and secrete B-cell lymphoma 2 (BCL-2), survivin, VEGF, HGF, insulin-like growth factor-I (IGF-I), stanniocalcin-1 (STC1), TGF- $\beta$, FGF, and granulocyte-macrophage colonystimulating factor (GM-CSF), which inhibit cellular apoptosis and restore tissue homeostasis [198-203]. BCL-2 is a classic inhibitor of apoptosis. An increased ratio of BCL-2 to BCL-2-associated X protein (BAX) results in cells that are less sensitive to the pathological stimuli and prevents cells from responding to apoptotic signals [204, 205]. 
Transplantation of autologous MSCs significantly downregulates Bax expression levels in the ischemic myocardium [206]. Zhang et al. demonstrated that the Bcl-2 signalling pathway, together with PI3K/Akt, closely participates in the anti-apoptotic action of MSCs against stroke [207]. Pan et al. demonstrated that MSCs ameliorate hepatic ischemia/reperfusion injuries via inactivation of the MEK/ERK signalling pathway in rats. Meanwhile, MSC-conditioned medium could down-regulate Bax, TNF receptor superfamily, member 6 (FAS), and caspase 3 (CASP3) levels in a human normal liver cell line under ischemic conditions, indicating the anti-apoptotic effects of MSC paracrine function [208]. MSC-derived chemokine (C motif) ligand (XCL1) has been reported to inhibit apoptosis in C2C12 cells [198]. However, direct XCL1 treatment showed no anti-apoptotic capacity.

In addition to the direct inhibition of apoptosis, MSCsecreted factors enhance cell survival by suppressing apoptotic pathways. The levels of VEGF, HGF, IGF-I, FGF, and GM-CSF in MSC culture medium have been found to be significantly elevated under hypoxic conditions [201]. Notably, upregulation of VEGF under hypoxia is greater than that of the other factors [199]. VEGF has been reported to inhibit serum starvation-induced vascular endothelial cell apoptosis via upregulating Bcl-2 expression [209]. VEGF also contributes to suppressing $\mathrm{p} 53$-mediated apoptosis via the activating phosphorylation of focal adhesion kinase (FAK), which is essential for regulating cell survival [210, 211].

\section{Antioxidative factors}

Reactive oxygen species (ROS), including oxygen ions, oxygen-free radicals, and peroxides, are byproducts of normal aerobic metabolism. ROS are involved in the regulation of multiple signalling pathways including cell proliferation, survival, and inflammation [212-214]. An imbalance between levels of ROS and antioxidant function leads to ROS-related diseases such as ageing, carcinogenesis, immune disorders, inflammation, multiple sclerosis, and neurodegeneration [129, 215]. Further, MSCs modulate the redox context via secretion of STC1, heme oxygenase-1 (HO-1), and glial-derived neurotrophic factor (GDNF) [216-218]. MSC-derived STC1 reduces ROS-induced apoptosis. Liu et al. demonstrated that STC1 suppresses angiotensin II-induced superoxide generation in cardiomyocytes via the uncoupling protein 3 (UCP3)-mediated anti-oxidant pathway [219]. Moreover, MSC-derived STC1 enhances the uncoupling respiration of mitochondria, reduces oxidative stress, and promotes the survival of alveolar epithelial cells under harmful microenvironments via upregulation of uncoupling protein 2 (UCP2) [220]. Furthermore, Ono et al. found that STC1 contributes to the ability of MSCs to ameliorate lung fibrosis via inhibition of the ROS/endoplasmic reticulum stress (ER-stress)/TGF- $\beta 1$ pathway [221].
Oh et al. found that STC1 can also respond to activated macrophages by inhibiting activation of the NLRP3 inflammasome, which decreases mitochondrial ROS production [222]. MSC-derived antioxidative enzyme HO-1 protects against oxidative injury. Allogeneic MSC transplantation ameliorates the redox environment via upregulating HO-1 in a rat model of lipopolysaccharide (LPS)-induced acute lung injury [217]. Chen et al. further demonstrated that HO-1 exerts a protective effect by elevating the activity of nuclear factor-erythroid 2 (NF-E2) p45-related factor-2 (Nrf2), which is a transcription factor mediating the Nrf2-antioxidant response element signalling pathway [223, 224]. HO-1 also attenuates LPS-induced inflammatory and oxidative damage via the enhanced paracrine function of stem cells. Zarjou et al. found that the production of HGF, SDF-1 and VEGF is significantly reduced in $\mathrm{HO}-1^{-1-}$ MSCs [225]. MSCs exert localized neuroprotection from oxidative stress by the secretion of GDNF [218, 226]. Lv et al. found that GDNF possibly prevents and repairs neuronal injury by regulating the MEK/ERK and the PI3K/AKT signalling pathways [227]. MSCs secrete different antioxidative factors in different experimental settings and diseases, probably due to the variation of ROS in localized microenvironments.

\section{Cell-cell contact}

MSCs exert their modulatory functions to host cells at damaged sites via paracrine action and direct cell-cell contact. MSCs modulate both autologous and allogeneic T lymphocytes via the expression of integrins (alpha 1 - alpha 6 , alpha $\mathrm{V}$, and beta 1 - beta 4), intercellular adhesion molecules (ICAM-1, ICAM-2), vascular cell adhesion protein (VCAM)-1, CD72, and CD58 (LFA-3) on their surfaces [6]. Accumulating evidence has shown that MSCs modulate $\mathrm{T}$ cells by the negative costimulatory molecule B7-H4, Fas-L/Fas interaction, or PD-L1/programmed death-1 (PD1) pathways [228-230]. Kovach et al. demonstrated that the expression of ICAM- 1 and VCAM-1 on MSCs is critical for maintaining their immunomodulatory functions on various subtypes of T cells [231]. The expression of PD-1 ligand on the surface of MSCs is critical for the contact-dependent inhibition of allogeneic Th17 differentiation [232]. Galectin-1 and galectin-3 are necessary for MSCs to inhibit the proliferation of $\mathrm{CD}^{+}$and $\mathrm{CD} 8^{+} \mathrm{T}$ cells [233].

Direct cell-cell contact is required for MSCs to induce Treg cells and in allergic diseases [106, 234]. It has been reported that increased gene expression of the Notch ligand, Delta-like 1, is essential for augmented Treg cell induction by toll-like receptor (TLR)-activated MSCs, which is dependent on cell-cell contact [7]. In addition, MSCs require cell-cell contact to reduce NK-cell cytotoxicity [235]. When co-cultured with MSCs, NK cells acquire CD73 expression, which makes the cells capable of converting adenosine 
5 '-monophosphate into adenosine for immunomodulatory purposes [236]. Li et al. found that cell-cell contact with pro-inflammatory macrophages enhances TSG-6 production by MSCs, thereby elevating the immunomodulatory effect of MSCs on T cells and macrophages. Pro-inflammatory macrophages in contact with MSCs also upregulate CD200 on stem cells, and skew the reprogramming of macrophages towards an anti-inflammatory phenotype through the interaction of CD200 with CD200R on pro-inflammatory macrophages [237]. Zhang et al. found that MSCs drive mature DCs to differentiate into regulatory DCs via contactdependent activation of Jagged-2 [238]. Furthermore, direct cell-cell contact between MSCs and endothelial progenitor cells induces MSC differentiation towards a pericyte-like phenotype, which may benefit angiogenesis for cell-based tissue-engineered bone grafts [239]. However, intravenously administered MSCs inhibit endothelial cell proliferation and angiogenesis via cell-cell contact through modulation of the VE-Cadherin/ $\beta$-catenin signalling pathways [240]. Therefore, the contact-dependent factors affecting the biology of adjacent responder cells and tissues should be carefully considered for optimization of the strategies involving MSCs.

\section{Mitochondrial transfer}

Mitochondria play important roles in the regulation of oxidative phosphorylation, generation of ATP, and cellular apoptosis. Dysfunctional mitochondria lead to excessive ROS production and cause oxidative damage in cells [241]. Accumulating evidence has suggested that mitochondrial transfer from MSCs is a novel strategy for the regeneration of various damaged cells via rescue of their respiratory activities. Accumulating evidence has shown that mitochondrial transfer occurs via TNTs, gap junctions, microvesicles, cell fusion and transfer of isolated mitochondria [132, 242-245]. So far, mitochondrial transfer from MSCs has demonstrated protective effects in lung injury, bronchial epithelial injury, allergic diseases, damaged cardiomyocytes, alkali-burnt corneal epithelial cells, kidney injury, ischemic damage, neurotoxicity, and spinal cord injury [132, 246-253]. Numerous studies have identified several signals including release of damaged mitochondria, mtDNA and mitochondrial products along with elevated ROS levels that trigger mitochondrial transfer from MSCs to the recipient cells [241].

Mitochondrial transfer through TNT has been intensively investigated between MSCs and damaged cells. Miro1 (mitochondrial Rho-GTPase 1, synonym: RhoT1), a calcium-sensitive adaptor protein, has been identified as one of the key regulators in mediating the transport of mitochondria. Miro1 binds the mitochondria to KIF5 motor protein together with other accessory proteins like Miro2, TRAK1, TRAK2, Myo10, and Myo19, thus forming a motor-adaptor complex that coordinates the mitochondrial movement at intercellular and intracellular levels [241, 242]. Knock-down of Miro1 in MSCs inhibits mitochondrial donation, thus reducing their therapeutic effects in bronchial epithelial injury [254]; in contrast, Miroloverexpression in MSCs leads to enhanced beneficial effects [242, 255, 256]. Apart from Miro1, Zhang et al. found that TNF- $\alpha$ induces TNT formation in MSCs via the TNF- $\alpha / N F-\kappa B / T N F \alpha I P 2$ signalling pathway, which facilitates mitochondrial transfer to cardiomyocytes. It has been reported that ROS signals can stimulate TNT formation [251]. Moreover, connexin 43 (CX43) is involved in regulating mitochondrial transfer from MSCs via TNT formation. CX43 overexpression in iPSC-MSCs enhances TNT formations and improves the mitochondrial transfer efficacy between MSCs and damaged epithelial cells. Knock-down of CX43 reduces TNT formation and thus decreases mitochondrial transfer from MSCs to damaged epithelial cells, impairing their immunomodulatory effects during allergic airway inflammation [105].

Additionally, gap junction channels play a critical role in mediating the mitochondrial transfer of MSCs. Islam et al. revealed that MSCs formed CX43-containing gap junction channels with alveolar epithelia in mice with acute lung injury, and released mitochondria-containing microvesicles that were subsequently engulfed by the epithelia. MSCs with genetically modified CX43 failed to adhere to alveolar epithelium and transfer mitochondria [132]. Pacak et al. demonstrated that cardiomyocytes could uptake the mitochondria isolated from MSCs through actin-dependent endocytosis [257]. Sinclair et al. summarized different modes of intercellular communication and mitochondrial transfer by MSCs. Retinoic acid, a gap junction potentiator, greatly enhances the mitochondrial transfer efficiency from BM-MSCs to neurons, and this effect is partially abrogated by $18 \beta$ glycyrrhetinic acid, which is a gap junction potentiator [253]. Inhibiting microtubule/TNTs, gap junction formation, or microvesicle endocytosis abrogates the transfer of cytoplasmic material from MSCs to epithelial cells [258]. Notably, MSCs can donate mitochondria to macrophages via extracellular vesicles, thus promoting an anti-inflammatory macrophage phenotype in acute respiratory distress syndrome [259]. Different pathophysiological conditions may initialize different modes of mitochondrial transfer, though their potential mechanisms remain unclear. Therefore, clarifying the relative mechanisms involved in mitochondrial transfer will advance the understanding of molecules involved in this process and serve to improve MSC treatment.

\section{Extracellular vesicles (exosomes)}

Extracellular vesicles (EVs), the membrane-bound vesicles released by somatic cell, are involved in tissue repair, immunomodulation, and proliferation [260-262]. EVs are classified into exosomes (30-150 nm endosome-derived plasma 
membrane-coated vesicles), microvesicles (100-1000 nm non-endocytic origin vesicles) and apoptotic bodies (1-5 $\mu \mathrm{m}$ vesicles released by apoptotic cells) according to their size and biogenesis. The most common EV markers are ALG2-interacting protein $\mathrm{X}$ (Alix), tetraspanin proteins CD9, CD63, CD81 and heat-shock protein (Hsp)60, Hsp70, and Hsp90. In addition, MSC-released EVs express unique surface antigens including CD44, CD73, CD90 and CD105 [263].

EVs, especially exosomes purified from MSCs have attracted great attention due to their regenerative, immunomodulatory, and even anti-tumour properties. Over the past decade, MSC-EVs have been found to exhibit various biological effects and have emerged as a novel approach for treating a variety of diseases. They overcome some limitations of MSC-based therapies including allogeneic immune rejection, malignant transformation, and premature cell differentiation. EVs have the unique capability to cross the blood-brain barrier, which is very important in the treatment of neurological disorders [263]. This means that EVs have better advantages in the clinic in the treatment of nervous system diseases as compared to the therapeutic potential of MSCs. Moreover, MSC-EVs can avoid the risk of genetic changes associated with stem cell transplantation for the treatment of nerve disorders [264, 265]. Remarkably, MSCEVs can be modified to carry specific proteins or genes that promote cellular function and tissue repair. These characteristics make the EVs an ideal candidate of treatment for regenerative medicine.

MSC-EVs enhance angiogenesis owing to their specific protein and transcript contents related to angiogenic and proliferative function [266, 267]. Anderson et al. further demonstrated that the protein content in MSC exosomes mediates angiogenesis via regulation of the NF- $\mathrm{KB}$ signalling pathway [267]. Nakamura et al. reported that MSC-derived exosomes promote muscle regeneration by enhancing angiogenesis and myogenesis, which is partially mediated by miR-494 [268]. Feng et al. demonstrated that miR-22 in MSC exosomes prevents apoptosis and reduces the infarct size in the heart by targeting methyl CpG binding protein 2 (Mecp2) [269]. In addition, miR-223 in MSC-EVs is involved in mediating cardioprotection via targeting semaphorin-3A (Sema3A) and transcription 3 (Stat3) [270]. miR-19a contributes to the anti-apoptotic effects of MSC exosomes in cardioprotection [271]. MSC exosomal miRNAs (miR-21, miR-23a, miR$125 \mathrm{~b}$ and miR-145) contribute to the suppression of myofibroblast formation by inhibiting TGF- $\beta 2 / \mathrm{Smad} 2$ signalling and reducing scar formation during wound healing [272]. Tomasoni et al. reported that MSC exosomes improve renal cell survival and proliferation by transferring the mRNA for insulin-like growth factor 1 receptor (IGF-1R), which increases the sensitization of proximal tubular cells to IGF-1 [273]. Currently, several strategies are under exploration that aim to enhance the exosomes released from MSCs. Hypoxia can facilitate MSCs to release exosomes, thus improving repair of cardiac tissues in a mouse model of myocardial infarction [274]. Compared with MSCs, exosomes derived from SDF1-overexpressing MSCs show enhanced therapeutic effects in myocardial infarction by increasing cardiac endothelial microvascular regeneration and inhibiting cardiomyocyte apoptosis in mice [275].

MSC-EVs modulate the immune system by induction of anti-inflammatory cytokines and Treg cells, by inhibition of B lymphocytes, regulation of macrophage polarization, and mobilization of neutrophils [260, 276]. Zhang et al. found that MSC-derived exosomes induce monocytes to differentiate into macrophages via the myeloid differentiation primary response gene 88 (MYD88)-dependent TLR signalling pathway. Exosome-induced macrophages lead to Treg cell expansion by secretion of more IL-10 as compared to the macrophages induced by lipopolysaccharide [134]. miR-146a enhances macrophage polarization to anti-inflammatory M2 macrophages [271]. Di Trapani et al. further demonstrated that the immunosuppressive effect of EVs on $\mathrm{T}$ cells, B cells, and NK cells is also mediated by PD-L1 expression on their surface [277]. Additionally, Galectin-1, an endogenous leptin on the EV surface, was also found to be involved in the immunosuppressive effects on T lymphocytes [278]. Kerkela et al. also emphasized the importance of 5'-ectonucleotidase (CD73), which actively produces immunosuppressive adenosine [279].

MSC-EVs have shown positive outcomes in treating cancer. Anti-angiogenic miRNAs such as miR-16 and miR100 have been identified in MSC exosomes, which suppress angiogenesis by targeting VEGF in breast cancer cells [133, 280]. However, the crosstalk between MSCs and tumour cells through EVs can function either as a tumour suppressor or as a promoter [281, 282]. MSC exosomes may transfer CD73 on tumour cells, which can reduce activation of NK cell and T cell by metabolism of AMP to adenosine [283]. So far, MSC-derived exosomes have been reported to be involved in tumour growth, angiogenesis, metastasis, and invasion [284]. The discrepancy between these controversial behaviours may arise from issues related to different MSC sources, tumour types, stages of tumour growth, and genotypes. Therefore, the potential side effects of EV therapy must be carefully evaluated.

\section{The target cell profile}

One of the major mechanisms underlying MSC-based therapy is interaction with target cells. MSCs modulate their immunomodulatory effects by suppressing the proliferation and activity of $\mathrm{T}$ cells, promoting Treg cells, regulatory DCs and M2 macrophages in a myriad of inflammatory diseases [285]. In case of T cell suppression, Lin et al. examined 
the mRNA expression profiles in mouse $\mathrm{T}$ lymphocytes after MSC administration and found that 5 mRNAs including Ccll1, Ccl24, Ill3, Il33, and Earl1 were significantly altered [109]. Wang et al. further identified more than 800 differentially expressed long non-coding RNAs (lncRNAs) in mouse T lymphocytes, and lncRNAs MM9LINCRNAEXON12105+ and AK089315 were finally identified as potential targets of MSC treatment in T cells [107]. MSCs and Treg cells have been found to work and interact in a synergistic manner. Engela et al. demonstrated that Treg cells can induce IDO secretion in MSCs, which results in TNF- $\alpha$ reduction and induction of IL-10 in Treg cells and effector cells [286]. Different subtypes of Treg cells generated by MSCs have been identified including $\mathrm{CD} 4^{+} \mathrm{CD} 25^{+} \mathrm{Foxp} 3^{+}$ Treg cells and IL-10 producing type 1 Treg $(\operatorname{Tr} 1)$ cells [287]. There is a complex cross-talk between MSCs and macrophages, which cannot be simply explained by MSCderived anti-inflammatory factors. Braza et al. found that macrophages can phagocytose MSCs and alter their proinflammatory signature to M2 suppressive phenotype following contact with dead MSCs [288]. This behaviour may explain the profound long-term effects of MSC therapy. Therefore, the presence of MSCs alters the targeted cell profile, which in turn leads to further activation or 'licensing' of MSC therapy.

\section{Challenges in MSC-based therapy}

MSC-based therapies have made great progress over the last decades. However, the publications/clinical trials with mixed and contradictory results are preventing the advancement of MSCs into daily clinical application. These disparities are probably due to the large variability in key factors such as cell source (tissue, donor), dosage, administration route, and administration timing. Inconsistencies among these parameters significantly limit the therapeutic value of MSCs. Therefore, standardization of procedures of MSC isolation and expansion is crucial for upcoming clinical therapeutics. The in vivo administration route, timing, and dosage also require optimization. In this circumstance, an understanding of the characteristics and functional mechanisms of differently sourced MSCs is required. The therapeutic benefits of MSCs are contributed by their differentiation potential and immunomodulatory capacity. These potentials are strongly influenced by the tissue source of MSCs, the age and health condition of the donor or the ex vivo culture conditions before administration. Furthermore, the indications of the local disease microenvironment where MSCs are intended to be applied also determine the benefits of MSCs. As a result, preconditioning strategies are developed that boost the differentiation or immunomodulatory potential of MSCs in such scenarios. Hypoxic preconditioning is employed since physiological environments are often hypoxic, and MSCs cultured under such condition show enhanced viability and secretion of cytoprotective molecules. However, slight variations in the oxygen level may significantly influence the function of MSCs as they are highly sensitive to oxygen tension [289]. Preconditioning with cytokines such as IFN- $\gamma$ or TNF- $\alpha$ enhances immunomodulatory factor secretion by MSCs, but such effects have been reported as temporary $[69,290]$. Alternative tissue engineering approaches including three-dimensional culture and hydrogel encapsulation were employed to enhance MSC functions [291, 292]. The therapeutic potentials of MSCs are attributed to complex cellular and molecular mechanisms of action, and such mechanisms still require in-depth exploration for clinical application. Current researches have made great progress and are gaining advancements in enhancing the therapeutic properties of MSCs and creating specific criteria to establish the basics for clinical application of MSCs. Moreover, senescence of MSCs has also attracted significant attention during the past years. MSCs can only undergo very limited cell passages and prolonged expansion, inevitably leading to replicative senescence. MSCs isolated from aged individuals or from patients also exhibit a senescent phenotype and display decreased function.

\section{Conclusion}

The advantages of MSCs in immunomodulation and tissue repair have rendered the cells an important source for stem cell therapies. The potential and eligibility of allogeneic cells makes MSCs desirable for cellular transplantation. Based on the promising results in preclinical and clinical studies, the emerging commercially available MSC-based products have been approved globally. However, larger studies with more randomized, blinded, and controlled trials are desired to demonstrate the beneficial effects of MSCs. This implies that the mechanisms underlying MSC-based therapy should be addressed. So far, MSCs have been intensively investigated for their differentiation capacity, paracrine effects, flexible EV release, and direct-contact modulatory functions. Each mechanism contributes to the comprehensive process of MSC therapy. Nevertheless, mechanisms underlying the protective effects of MSCs still require further elucidation. MSCs can adapt therapeutic effects during the rescue and repair of damaged tissues according to diverse local microenvironments. Therefore, the in-depth mechanisms underlying the protective effects of MSCs require further investigation. Clarification of the predominant mechanisms in different situations will improve the safety, efficacy and outcomes of MSC-based therapy. 
Acknowledgements This work was supported by grants from National Natural Science Foundation of China (81471832, 81671882, 81770984,81970863 and 81900919), the key grant from the Science and Technology Foundation of Guangdong Province of China (2015B020225001) and the Natural Science Foundation of Guangdong Province (2014A030313051, 2016A030308017, 2017A030313105).

Author contributions X.L.F., Y.Z., X.L. wrote the manuscript; Q.L.F. designed and wrote the manuscript.

\section{Compliance with ethical standards}

Conflict of interest The authors declare that they have no conflict of interest.

Open Access This article is licensed under a Creative Commons Attribution 4.0 International License, which permits use, sharing, adaptation, distribution and reproduction in any medium or format, as long as you give appropriate credit to the original author(s) and the source, provide a link to the Creative Commons licence, and indicate if changes were made. The images or other third party material in this article are included in the article's Creative Commons licence, unless indicated otherwise in a credit line to the material. If material is not included in the article's Creative Commons licence and your intended use is not permitted by statutory regulation or exceeds the permitted use, you will need to obtain permission directly from the copyright holder. To view a copy of this licence, visit http://creativecommons.org/licenses/by/4.0/.

\section{References}

1. Spees JL, Lee RH, Gregory CA (2016) Mechanisms of mesenchymal stem/stromal cell function. Stem Cell Res Ther 7(1):125. https://doi.org/10.1186/s13287-016-0363-7

2. Friedenstein AJ, Piatetzky S II, Petrakova KV (1966) Osteogenesis in transplants of bone marrow cells. J Embryol Exp Morphol 16(3):381-390

3. Vilquin JT, Rosset P (2006) Mesenchymal stem cells in bone and cartilage repair: current status. Regen Med 1(4):589-604. https ://doi.org/10.2217/17460751.1.4.589

4. Kean TJ, Lin P, Caplan AI, Dennis JE (2013) MSCs: delivery routes and engraftment, cell-targeting strategies, and immune modulation. Stem Cells Int 2013:732742. https://doi. org/10.1155/2013/732742

5. Caplan AI, Dennis JE (2006) Mesenchymal stem cells as trophic mediators. J Cell Biochem 98(5):1076-1084. https://doi. org/10.1002/jcb.20886

6. Fan XL, Zhang Z, Ma CY, Fu QL (2019) Mesenchymal stem cells for inflammatory airway disorders: promises and challenges. Biosci Rep. https://doi.org/10.1042/BSR20182160

7. Li F, Guo X, Chen SY (2017) Function and therapeutic potential of mesenchymal stem cells in atherosclerosis. Front Cardiovasc Med 4:32. https://doi.org/10.3389/fcvm.2017.00032

8. Ullah I, Subbarao RB, Rho GJ (2015) Human mesenchymal stem cells - current trends and future prospective. Biosci Rep. https:// doi.org/10.1042/BSR20150025

9. Dominici M, Le Blanc K, Mueller I, Slaper-Cortenbach I, Marini F, Krause D, Deans R, Keating A, Prockop D, Horwitz E (2006) Minimal criteria for defining multipotent mesenchymal stromal cells. The international society for cellular therapy position statement. Cytotherapy 8(4):315-317. https://doi.org/10.1080/14653 240600855905
10. Qin Y, Guan J, Zhang C (2014) Mesenchymal stem cells: mechanisms and role in bone regeneration. Postgrad Med J 90(1069):643-647. https://doi.org/10.1136/postgradmedj-2013132387

11. Nash ME, Fan X, Carroll WM, Gorelov AV, Barry FP, Shaw G, Rochev YA (2013) Thermoresponsive substrates used for the expansion of human mesenchymal stem cells and the preservation of immunophenotype. Stem Cell Rev 9(2):148-157. https:// doi.org/10.1007/s12015-013-9428-5

12. Lama VN, Smith L, Badri L, Flint A, Andrei AC, Murray S, Wang Z, Liao H, Toews GB, Krebsbach PH, Peters-Golden M, Pinsky DJ, Martinez FJ, Thannickal VJ (2007) Evidence for tissue-resident mesenchymal stem cells in human adult lung from studies of transplanted allografts. J Clin Invest 117(4):989-996. https://doi.org/10.1172/JCI29713

13. Yannarelli G, Pacienza N, Cuniberti L, Medin J, Davies J, Keating A (2013) Brief report: The potential role of epigenetics on multipotent cell differentiation capacity of mesenchymal stromal cells. Stem Cells 31(1):215-220. https://doi.org/10.1002/ stem. 1262

14. Zuk PA, Zhu M, Ashjian P, De Ugarte DA, Huang JI, Mizuno H, Alfonso ZC, Fraser JK, Benhaim P, Hedrick MH (2002) Human adipose tissue is a source of multipotent stem cells. Mol Biol Cell 13(12):4279-4295. https://doi.org/10.1091/mbc. e02-02-0105

15. Campagnoli C, Roberts IA, Kumar S, Bennett PR, Bellantuono I, Fisk NM (2001) Identification of mesenchymal stem/progenitor cells in human first-trimester fetal blood, liver, and bone marrow. Blood 98(8):2396-2402

16. Anker PS, Scherjon SA, Kleijburg-van der Keur C, Noort WA, Claas FH, Willemze R, Fibbe WE, Kanhai HH (2003) Amniotic fluid as a novel source of mesenchymal stem cells for therapeutic transplantation. Blood 102(4):1548-1549. https://doi. org/10.1182/blood-2003-04-1291

17. Erices A, Conget P, Minguell JJ (2000) Mesenchymal progenitor cells in human umbilical cord blood. Br J Haematol 109(1):235-242

18. De Bari C, Dell'Accio F, Tylzanowski P, Luyten FP (2001) Multipotent mesenchymal stem cells from adult human synovial membrane. Arthritis Rheum 44(8):1928-1942. https://doi. org/10.1002/1529-0131(200108)44:8\%3c1928:AID-ART33 $1 \% 3 \mathrm{e} 3.0 . \mathrm{CO} ; 2-\mathrm{P}$

19. Kuznetsov SA, Mankani MH, Gronthos S, Satomura K, Bianco P, Robey PG (2001) Circulating skeletal stem cells. J Cell Biol 153(5):1133-1140

20. Tondreau T, Meuleman N, Delforge A, Dejeneffe M, Leroy R, Massy M, Mortier C, Bron D, Lagneaux L (2005) Mesenchymal stem cells derived from CD133-positive cells in mobilized peripheral blood and cord blood: proliferation, Oct4 expression, and plasticity. Stem Cells 23(8):1105-1112. https://doi. org/10.1634/stemcells.2004-0330

21. Carlotti F, Zaldumbide A, Loomans CJ, van Rossenberg E, Engelse M, de Koning EJ, Hoeben RC (2010) Isolated human islets contain a distinct population of mesenchymal stem cells. Islets 2(3):164-173. https://doi.org/10.4161/isl.2.3.11449

22. Paul G, Ozen I, Christophersen NS, Reinbothe T, Bengzon J, Visse E, Jansson K, Dannaeus K, Henriques-Oliveira C, Roybon L, Anisimov SV, Renstrom E, Svensson M, Haegerstrand A, Brundin P (2012) The adult human brain harbors multipotent perivascular mesenchymal stem cells. PLoS ONE 7(4):e35577. https://doi.org/10.1371/journal.pone.0035577

23. Huang F, Chen M, Chen W, Gu J, Yuan J, Xue Y, Dang J, Su W, Wang J, Zadeh HH, He X, Rong L, Olsen N, Zheng SG (2017) Human gingiva-derived mesenchymal stem cells inhibit xenograft-versus-host disease via CD39-CD73-adenosine and IDO 
signals. Front Immunol 8:68. https://doi.org/10.3389/fimmu .2017 .00068

24. Ukai R, Honmou O, Harada K, Houkin K, Hamada H, Kocsis JD (2007) Mesenchymal stem cells derived from peripheral blood protects against ischemia. J Neurotrauma 24(3):508-520. https ://doi.org/10.1089/neu.2006.0161

25. Berebichez-Fridman R, Montero-Olvera PR (2018) Sources and clinical applications of mesenchymal stem cells: state-of-the-art review. Sultan Qaboos Univ Med J 18(3):e264-e277. https://doi. org/10.18295/squmj.2018.18.03.002

26. Via AG, Frizziero A, Oliva F (2012) Biological properties of mesenchymal stem cells from different sources. Muscles Ligaments Tendons J 2(3):154-162

27. Wu M, Zhang R, Zou Q, Chen Y, Zhou M, Li X, Ran R, Chen Q (2018) Comparison of the biological characteristics of mesenchymal stem cells derived from the human placenta and umbilical cord. Sci Rep 8(1):5014. https://doi.org/10.1038/s41598-01823396-1

28. Vasandan AB, Shankar SR, Prasad P, Sowmya Jahnavi V, Bhonde RR, Jyothi Prasanna S (2014) Functional differences in mesenchymal stromal cells from human dental pulp and periodontal ligament. J Cell Mol Med 18(2):344-354. https://doi.org/10.1111/ jcmm.12192

29. Sakaguchi Y, Sekiya I, Yagishita K, Muneta T (2005) Comparison of human stem cells derived from various mesenchymal tissues - Superiority of synovium as a cell source. Arthritis Rheum 52(8):2521-2529. https://doi.org/10.1002/art.21212

30. Huibregtse BA, Johnstone B, Goldberg VM, Caplan AI (2000) Effect of age and sampling site on the chondro-osteogenic potential of rabbit marrow-derived mesenchymal progenitor cells. J Orthopaed Res 18(1):18-24. https://doi.org/10.1002/jor.11001 80104

31. Danisovic L, Varga I, Polak S, Ulicna M, Hlavackova L, Bohmer D, Vojtassak J (2009) Comparison of in vitro chondrogenic potential of human mesenchymal stem cells derived from bone marrow and adipose tissue. Gen Physiol Biophys 28(1):56-62

32. Gasiuniene M, Zentelyte A, Wojtas B, Baronaite S, Krasovskaja N, Savickiene J, Gielniewski B, Kaminska B, Utkus A, Navakauskiene R (2019) DNA methyltransferases inhibitors effectively induce gene expression changes suggestive of cardiomyogenic differentiation of human amniotic fluid-derived mesenchymal stem cells via chromatin remodeling. J Tissue Eng Regen Med 13(3):469-481. https://doi.org/10.1002/term.2800

33. Park J, Lee JH, Yoon BS, Jun EK, Lee G, Kim IY, You S (2018) Additive effect of bFGF and selenium on expansion and paracrine action of human amniotic fluid-derived mesenchymal stem cells. Stem Cell Res Ther 9(1):293. https://doi.org/10.1186/s1328 7-018-1058-Z

34. Charbord P, Livne E, Gross G, Haupl T, Neves NM, Marie P, Bianco P, Jorgensen C (2011) Human bone marrow mesenchymal stem cells: a systematic reappraisal via the genostem experience. Stem Cell Rev 7(1):32-42. https://doi.org/10.1007/s1201 5-010-9125-6

35. Wang WG, Lou SQ, Ju XD, Xia K, Xia JH (2003) In vitro chondrogenesis of human bone marrow-derived mesenchymal progenitor cells in monolayer culture: activation by transfection with TGF-beta2. Tissue Cell 35(1):69-77

36. Violini S, Ramelli P, Pisani LF, Gorni C, Mariani P (2009) Horse bone marrow mesenchymal stem cells express embryo stem cell markers and show the ability for tenogenic differentiation by in vitro exposure to BMP-12. BMC Cell Biol. https://doi. org/10.1186/1471-2121-10-29

37. Delorme B, Ringe J, Pontikoglou C, Gaillard J, Langonne A, Sensebe L, Noel D, Jorgensen C, Haupl T, Charbord P (2009) Specific lineage-priming of bone marrow mesenchymal stem cells provides the molecular framework for their plasticity. Stem Cells 27(5):1142-1151. https://doi.org/10.1002/stem.34

38. Arthur A, Rychkov G, Shi S, Koblar SA, Gronthos S (2008) Adult human dental pulp stem cells differentiate toward functionally active neurons under appropriate environmental cues. Stem Cells 26(7):1787-1795. https://doi.org/10.1634/stemc ells.2007-0979

39. Wang YX, Ma ZF, Huo N, Tang L, Han C, Duan YZ, Jin Y (2011) Porcine tooth germ cell conditioned medium can induce odontogenic differentiation of human dental pulp stem cells. J Tissue Eng Regen M 5(5):354-362. https://doi.org/10.1002/ term.321

40. Zhang WB, Walboomers XF, Shi ST, Fan MW, Jansen JA (2006) Multilineage differentiation potential of stem cells derived from human dental pulp after cryopreservation. Tissue Eng 12(10):2813-2823. https://doi.org/10.1089/ten.2006.12.2813

41. Luo LH, He Y, Wang XY, Key B, Lee BH, Li HQ, Ye QS (2018) Potential roles of dental pulp stem cells in neural regeneration and repair. Stem Cells Int. https://doi.org/10.1155/2018/1731289

42. Lu H, Wang F, Mei H, Wang S, Cheng L (2018) Human adipose mesenchymal stem cells show more efficient angiogenesis promotion on endothelial colony-forming cells than umbilical cord and endometrium. Stem Cells Int 2018:7537589. https:// doi.org/10.1155/2018/7537589

43. Wang X, Liu L, Mou S, Zhao H, Fang J, Xiang Y, Zhao T, Sha T, Ding J, Hao C (2018) Investigation of platelet-rich plasma in increasing proliferation and migration of endometrial mesenchymal stem cells and improving pregnancy outcome of patients with thin endometrium. J Cell Biochem. https://doi.org/10.1002/ jcb. 28014

44. Zvaifler NJ, Marinova-Mutafchieva L, Adams G, Edwards CJ, Moss J, Burger JA, Maini RN (2000) Mesenchymal precursor cells in the blood of normal individuals. Arthritis Res 2(6):477488. https://doi.org/10.1186/ar130

45. Sabapathy V, Ravi S, Srivastava V, Srivastava A, Kumar S (2012) Long-term cultured human term placenta-derived mesenchymal stem cells of maternal origin displays plasticity. Stem Cells Int 2012:174328. https://doi.org/10.1155/2012/174328

46. Oliveira MS, Barreto-Filho JB (2015) Placental-derived stem cells: Culture, differentiation and challenges. World J Stem Cells 7(4):769-775. https://doi.org/10.4252/wjsc.v7.i4.769

47. Yoshimura H, Muneta T, Nimura A, Yokoyama A, Koga H, Sekiya I (2007) Comparison of rat mesenchymal stem cells derived from bone marrow, synovium, periosteum, adipose tissue, and muscle. Cell Tissue Res 327(3):449-462. https://doi. org/10.1007/s00441-006-0308-z

48. De Bari C, Dell'Accio F, Vandenabeele F, Vermeesch JR, Raymackcrs JM, Luyten FP (2003) Skeletal muscle repair by adult human mesenchymal stem cells from synovial membrane. J Cell Biol 160(6):909-918. https://doi.org/10.1083/jcb.200212064

49. Lorenz K, Sicker M, Schmelzer E, Rupf T, Salvetter J, Schulz-Siegmund M, Bader A (2008) Multilineage differentiation potential of human dermal skin-derived fibroblasts. Exp Dermatol 17(11):925-932. https://doi.org/10.111 1/j.1600-0625.2008.00724.x

50. Vishnubalaji R, Manikandan M, Al-Nbaheen M, Kadalmani B, Aldahmash A, Alajez NM (2012) In vitro differentiation of human skin-derived multipotent stromal cells into putative endothelial-like cells. BMC Dev Biol. https://doi. org/10.1186/1471-213x-12-7

51. Shi CM, Cheng TM (2004) Differentiation of dermis-derived multipotent cells into insulin-producing pancreatic cells in vitro. World J Gastroentero 10(17):2550-2552. https://doi.org/10.3748/ wjg.v10.i17.2550

52. Conconi MT, Burra P, Di Liddo R, Calore C, Turetta M, Bellini S, Bo P, Nussdorfer GG, Parnigotto PP (2006) CD105(+) cells 
from Wharton's jelly show in vitro and in vivo myogenic differentiative potential. Int J Mol Med 18(6):1089-1096

53. Wu KH, Zhou B, Lu SH, Feng B, Yang SG, Du WT, Gu DS, Han ZC, Liu YL (2007) In vitro and in vivo differentiation of human umbilical cord derived stem cells into endothelial cells. J Cell Biochem 100(3):608-616. https://doi.org/10.1002/jcb.21078

54. Trivedi P, Hematti P (2008) Derivation and immunological characterization of mesenchymal stromal cells from human embryonic stem cells. Exp Hematol 36(3):350-359

55. Lian Q, Zhang Y, Zhang J, Zhang HK, Wu X, Zhang Y, Lam FF, Kang S, Xia JC, Lai WH, Au KW, Chow YY, Siu CW, Lee CN, Tse HF (2010) Functional mesenchymal stem cells derived from human induced pluripotent stem cells attenuate limb ischemia in mice. Circulation 121(9):1113-1123. https://doi.org/10.1161/ CIRCULATIONAHA.109.898312

56. Lian Q, Zhang Y, Liang X, Gao F, Tse HF (2016) Directed differentiation of human-induced pluripotent stem cells to mesenchymal stem cells. Methods Mol Biol 1416:289-298. https://doi. org/10.1007/978-1-4939-3584-0_17

57. Gao WX, Sun YQ, Shi J, Li CL, Fang SB, Wang D, Deng XQ, Wen W, Fu QL (2017) Effects of mesenchymal stem cells from human induced pluripotent stem cells on differentiation, maturation, and function of dendritic cells. Stem Cell Res Ther 8(1):48. https://doi.org/10.1186/s13287-017-0499-0

58. Sun YQ, Zhang Y, Li X, Deng MX, Gao WX, Yao Y, Chiu SM, Liang X, Gao F, Chan CW, Tse HF, Shi J, Fu QL, Lian Q (2015) Insensitivity of human iPS cells-derived mesenchymal stem cells to interferon-gamma-induced hla expression potentiates repair efficiency of hind limb ischemia in immune humanized nod scid gamma mice. Stem Cells 33(12):3452-3467. https:// doi.org/10.1002/stem.2094

59. Spitzhorn LS, Megges M, Wruck W, Rahman MS, Otte J, Degistirici O, Meisel R, Sorg RV, Oreffo ROC, Adjaye J (2019) Human iPSC-derived MSCs (iMSCs) from aged individuals acquire a rejuvenation signature. Stem Cell Res Ther 10(1):100. https:// doi.org/10.1186/s13287-019-1209-x

60. Perez-Silos V, Camacho-Morales A, Fuentes-Mera L (2016) Mesenchymal stem cells subpopulations: application for orthopedic regenerative medicine. Stem Cells Int 2016:3187491. https ://doi.org/10.1155/2016/3187491

61. Pittenger MF, Mackay AM, Beck SC, Jaiswal RK, Douglas R, Mosca JD, Moorman MA, Simonetti DW, Craig S, Marshak DR (1999) Multilineage potential of adult human mesenchymal stem cells. Science 284(5411):143-147

62. Kim N, Cho SG (2013) Clinical applications of mesenchymal stem cells. Korean J Intern Med 28(4):387-402. https://doi. org/10.3904/kjim.2013.28.4.387

63. Badylak SF, Weiss DJ, Caplan A, Macchiarini P (2012) Engineered whole organs and complex tissues. Lancet 379(9819):943952. https://doi.org/10.1016/S0140-6736(12)60073-7

64. Pereira RF, Halford KW, O'Hara MD, Leeper DB, Sokolov BP, Pollard MD, Bagasra O, Prockop DJ (1995) Cultured adherent cells from marrow can serve as long-lasting precursor cells for bone, cartilage, and lung in irradiated mice. Proc Natl Acad Sci USA 92(11):4857-4861

65. Schwartz RE, Reyes M, Koodie L, Jiang YH, Blackstad M, Lund T, Lenvik T, Johnson S, Hu WS, Verfaillie CM (2002) Multipotent adult progenitor cells from bone marrow differentiate into functional hepatocyte-like cells. J Clin Invest 109(10):12911302. https://doi.org/10.1172/Jci200215182

66. Dai WD, Hale SL, Martin BJ, Kuang JQ, Dow JS, Wold LE, Kloner RA (2005) Allogeneic mesenchymal stem cell transplantation in postinfarcted rat myocardium - Short- and long-term effects. Circulation 112(2):214-223. https://doi.org/10.1161/ Circulationaha.104.527937
67. Bae JS, Han HS, Youn DH, Carter JE, Modo M, Schuchman EH, Jin HK (2007) Bone marrow-derived mesenchymal stem cells promote neuronal networks with functional synaptic transmission after transplantation into mice with neurodegeneration. Stem Cells 25(5):1307-1316. https://doi.org/10.1634/stemc ells.2006-0561

68. Sharma K, Husain SY, Das P, Hussain M, Syed MA (2017) Regenerative Potential of Mesenchymal Stem Cells: Therapeutic Applications in Lung Disorders. In: Pham PV (ed) Liver, Lung and Heart Regeneration. Springer International Publishing, Cham, pp 77-117. doi:10.1007/978-3-319-46693-4_6

69. Gao F, Chiu SM, Motan DAL, Zhang Z, Chen L, Ji HL, Tse HF, Fu QL, Lian Q (2016) Mesenchymal stem cells and immunomodulation: current status and future prospects. Cell Death Dis. https://doi.org/10.1038/cddis.2015.327

70. Fan XL, Zeng QX, Li X, Li CL, Xu ZB, Deng XQ, Shi J, Chen D, Zheng SG, Fu QL (2018) Induced pluripotent stem cell-derived mesenchymal stem cells activate quiescent $\mathrm{T}$ cells and elevate regulatory $\mathrm{T}$ cell response via NF-kappaB in allergic rhinitis patients. Stem Cell Res Ther 9(1):170. https://doi.org/10.1186/ s13287-018-0896-Z

71. Selmani Z, Naji A, Zidi I, Favier B, Gaiffe E, Obert L, Borg C, Saas P, Tiberghien P, Rouas-Freiss N, Carosella ED, Deschaseaux F (2008) Human leukocyte antigen-G5 secretion by human mesenchymal stem cells is required to suppress $\mathrm{T}$ lymphocyte and natural killer function and to induce CD4(+)CD25(high) FOXP3(+) regulatory T cells. Stem Cells 26(1):212-222. https ://doi.org/10.1634/stemcells.2007-0554

72. Augello A, Tasso R, Negrini SM, Amateis A, Indiveri F, Cancedda R, Pennesi G (2005) Bone marrow mesenchymal progenitor cells inhibit lymphocyte proliferation by activation of the programmed death 1 pathway. Eur J Immunol 35(5):1482-1490. https://doi.org/10.1002/eji.200425405

73. Corcione A, Benvenuto F, Ferretti E, Giunti D, Cappiello V, Cazzanti F, Risso M, Gualandi F, Mancardi GL, Pistoia V, Uccelli A (2006) Human mesenchymal stem cells modulate B-cell functions. Blood 107(1):367-372. https://doi. org/10.1182/blood-2005-07-2657

74. Spaggiari GM, Capobianco A, Abdelrazik H, Becchetti F, Mingari MC, Moretta L (2008) Mesenchymal stem cells inhibit natural killer-cell proliferation, cytotoxicity, and cytokine production: role of indoleamine 2,3-dioxygenase and prostaglandin E2. Blood 111(3):1327-1333. https://doi.org/10.1182/ blood-2007-02-074997

75. Vacca P, Vitale C, Munari E, Cassatella MA, Mingari MC, Moretta L (2018) Human innate lymphoid cells: their functional and cellular interactions in Decidua. Front Immunol. https://doi.org/10.3389/fimmu.2018.01897

76. van Hoeven V, Munneke JM, Cornelissen AS, Omar SZ, Spruit MJ, Kleijer M, Bernink JH, Blom B, Voermans C, Hazenberg MD (2018) Mesenchymal stromal cells stimulate the proliferation and il-22 production of group 3 innate lymphoid cells. J Immunol 201(4):1165-1173. https://doi.org/10.4049/jimmu nol.1700901

77. Zhang L, Yu J, Wei W (2018) Advance in targeted immunotherapy for graft-versus-host disease. Front Immunol 9:1087. https://doi.org/10.3389/fimmu.2018.01087

78. Marigo I, Dazzi F (2011) The immunomodulatory properties of mesenchymal stem cells. Semin Immunopathol 33(6):593-602. https://doi.org/10.1007/s00281-011-0267-7

79. Li Y, Wu Q, Wang Y, Li L, Bu H, Bao J (2017) Senescence of mesenchymal stem cells (Review). Int J Mol Med 39(4):775782. https://doi.org/10.3892/ijmm.2017.2912

80. Yang YK, Ogando CR, Wang See C, Chang TY, Barabino GA (2018) Changes in phenotype and differentiation potential of 
human mesenchymal stem cells aging in vitro. Stem Cell Res Ther 9(1):131. https://doi.org/10.1186/s13287-018-0876-3

81. Fafian-Labora JA, Morente-Lopez M, Arufe MC (2019) Effect of aging on behaviour of mesenchymal stem cells. World $\mathbf{J}$ Stem Cells 11(6):337-346. https://doi.org/10.4252/wjsc.v11. i6.337

82. Song HF, He S, Li SH, Yin WJ, Wu J, Guo J, Shao ZB, Zhai XY, Gong H, Lu L, Wei F, Weisel RD, Xie J, Li RK (2017) Aged human multipotent mesenchymal stromal cells can be rejuvenated by neuron-derived neurotrophic factor and improve heart function after injury. JACC Basic Transl Sci 2(6):702-716. https ://doi.org/10.1016/j.jacbts.2017.07.014

83. Dong J, Zhang ZH, Huang HS, Mo P, Cheng CF, Liu JW, Huang WZ, Tian CW, Zhang CY, Li J (2018) miR-10a rejuvenates aged human mesenchymal stem cells and improves heart function after myocardial infarction through KLF4. Stem Cell Res Ther. https ://doi.org/10.1186/s13287-018-0895-0

84. Salminen A, Kauppinen A, Kaarniranta K (2017) FGF21 activates AMPK signaling: impact on metabolic regulation and the aging process. J Mol Med 95(2):123-131. https://doi. org/10.1007/s00109-016-1477-1

85. Liang J, Zhang H, Kong W, Deng W, Wang D, Feng X, Zhao C, Hua B, Wang H, Sun L (2018) Safety analysis in patients with autoimmune disease receiving allogeneic mesenchymal stem cells infusion: a long-term retrospective study. Stem Cell Res Ther 9(1):312. https://doi.org/10.1186/s13287-018-1053-4

86. Munir H, McGettrick HM (2015) Mesenchymal stem cell therapy for autoimmune disease: risks and rewards. Stem Cells Dev 24(18):2091-2100. https://doi.org/10.1089/scd.2015.0008

87. Shyam H, Singh SK, Kant R, Saxena SK (2017) Mesenchymal stem cells in regenerative medicine: a new paradigm for degenerative bone diseases. Regen Med 12(2):111-114. https://doi. org/10.2217/rme-2016-0162

88. White IA, Sanina C, Balkan W, Hare JM (2016) Mesenchymal stem cells in cardiology. Methods Mol Biol 1416:55-87. https ://doi.org/10.1007/978-1-4939-3584-0_4

89. Brychtova M, Thiele JA, Lysak D, Holubova M, Kralickova M, Vistejnova L (2019) Mesenchymal stem cells as the near future of cardiology medicine - truth or wish? Biomed Pap Med Fac Univ Palacky Olomouc Czech Repub 163(1):8-18. https://doi. org/10.5507/bp.2018.071

90. Broekman W, Khedoe P, Schepers K, Roelofs H, Stolk J, Hiemstra PS (2018) Mesenchymal stromal cells: a novel therapy for the treatment of chronic obstructive pulmonary disease? Tho$\operatorname{rax}$ 73(6):565-574. https://doi.org/10.1136/thoraxjnl-2017210672

91. Wang YH, Wu DB, Chen B, Chen EQ, Tang H (2018) Progress in mesenchymal stem cell-based therapy for acute liver failure. Stem Cell Res Ther 9(1):227. https://doi.org/10.1186/s1328 7-018-0972-4

92. Zhang Y, Li Y, Zhang L, Li J, Zhu C (2018) Mesenchymal stem cells: potential application for the treatment of hepatic cirrhosis. Stem Cell Res Ther 9(1):59. https://doi.org/10.1186/s1328 7-018-0814-4

93. Lee NK, Na DL, Chang JW (2018) Killing two birds with one stone: The multifunctional roles of mesenchymal stem cells in the treatment of neurodegenerative and muscle diseases. Histol Histopathol 33(7):629-638. https://doi.org/10.14670/HH-11-951

94. Volkman R, Offen D (2017) Concise review: mesenchymal stem cells in neurodegenerative diseases. Stem Cells 35(8):18671880. https://doi.org/10.1002/stem.2651

95. Lo Furno D, Mannino G, Giuffrida R (2018) Functional role of mesenchymal stem cells in the treatment of chronic neurodegenerative diseases. J Cell Physiol 233(5):3982-3999. https://doi. org/10.1002/jcp.26192
96. Dasari VR, Veeravalli KK, Dinh DH (2014) Mesenchymal stem cells in the treatment of spinal cord injuries: a review. World $\mathbf{J}$ Stem Cells 6(2):120-133. https://doi.org/10.4252/wjsc.v6.i2.120

97. Lee HY, Hong IS (2017) Double-edged sword of mesenchymal stem cells: Cancer-promoting versus therapeutic potential. Cancer Sci 108(10):1939-1946. https://doi.org/10.1111/cas.13334

98. Garcia-Olmo D, Herreros D, Pascual I, Pascual JA, Del-Valle E, Zorrilla J, De-La-Quintana P, Garcia-Arranz M, Pascual M (2009) Expanded adipose-derived stem cells for the treatment of complex perianal fistula: a phase II clinical trial. Dis Colon Rectum 52(1):79-86. https://doi.org/10.1007/DCR.0b013e3181 973487

99. Liang J, Zhang H, Hua B, Wang H, Lu L, Shi S, Hou Y, Zeng X, Gilkeson GS, Sun L (2010) Allogenic mesenchymal stem cells transplantation in refractory systemic lupus erythematosus: a pilot clinical study. Ann Rheum Dis 69(8):1423-1429. https:// doi.org/10.1136/ard.2009.123463

100. Liang J, Gu F, Wang H, Hua B, Hou Y, Shi S, Lu L, Sun L (2010) Mesenchymal stem cell transplantation for diffuse alveolar hemorrhage in SLE. Nat Rev Rheumatol 6(8):486-489. https://doi. org/10.1038/nrrheum.2010.80

101. Ansboro S, Roelofs AJ, De Bari C (2017) Mesenchymal stem cells for the management of rheumatoid arthritis: immune modulation, repair or both? Curr Opin Rheumatol 29(2):201-207. https://doi.org/10.1097/bor.0000000000000370

102. Dunavin N, Dias A, Li M, McGuirk J (2017) Mesenchymal stromal cells: what is the mechanism in acute graft-versus-host disease? Biomedicines 5(3):39. https://doi.org/10.3390/biomedicin es5030039

103. Moreira A, Kahlenberg S, Hornsby P (2017) Therapeutic potential of mesenchymal stem cells for diabetes. J Mol Endocrinol 59(3):R109-R120. https://doi.org/10.1530/JME-17-0117

104. Sun YQ, Deng MX, He J, Zeng QX, Wen W, Wong DS, Tse HF, Xu G, Lian Q, Shi J, Fu QL (2012) Human pluripotent stem cell-derived mesenchymal stem cells prevent allergic airway inflammation in mice. Stem Cells 30(12):2692-2699. https:// doi.org/10.1002/stem.1241

105. Yao Y, Fan XL, Jiang D, Zhang Y, Li X, Xu ZB, Fang SB, Chiu S, Tse HF, Lian Q, Fu QL (2018) Connexin 43-mediated mitochondrial transfer of ipsc-mscs alleviates asthma inflammation. Stem Cell Rep 11(5):1120-1135. https://doi.org/10.1016/j.stemc r.2018.09.012

106. Fu QL, Chow YY, Sun SJ, Zeng QX, Li HB, Shi JB, Sun YQ, Wen W, Tse HF, Lian Q, Xu G (2012) Mesenchymal stem cells derived from human induced pluripotent stem cells modulate T-cell phenotypes in allergic rhinitis. Allergy 67(10):1215-1222. https://doi.org/10.1111/j.1398-9995.2012.02875.x

107. Wang SY, Fan XL, Yu QN, Deng MX, Sun YQ, Gao WX, Li CL, Shi JB, Fu QL (2017) The lncRNAs involved in mouse airway allergic inflammation following induced pluripotent stem cellmesenchymal stem cell treatment. Stem Cell Res Ther 8(1):2. https://doi.org/10.1186/s13287-016-0456-3

108. Li X, Michaeloudes C, Zhang Y, Wiegman CH, Adcock IM, Lian Q, Mak JCW, Bhavsar PK, Chung KF (2018) Mesenchymal stem cells alleviate oxidative stress-induced mitochondrial dysfunction in the airways. J Allergy Clin Immunol 141(5):1634-1645. https ://doi.org/10.1016/j.jaci.2017.08.017

109. Lin YD, Fan XL, Zhang H, Fang SB, Li CL, Deng MX, Qin ZL, Peng YQ, Zhang HY, Fu QL (2018) The genes involved in asthma with the treatment of human embryonic stem cell-derived mesenchymal stem cells. Mol Immunol 95:47-55. https://doi. org/10.1016/j.molimm.2018.01.013

110. Kavanagh H, Mahon BP (2011) Allogeneic mesenchymal stem cells prevent allergic airway inflammation by inducing murine regulatory T cells. Allergy 66(4):523-531. https://doi.org/10.11 $11 /$ j.1398-9995.2010.02509.x 
111. Mohammadian M, Boskabady MH, Kashani IR, Jahromi GP, Omidi A, Nejad AK, Khamse S, Sadeghipour HR (2016) Effect of bone marrow derived mesenchymal stem cells on lung pathology and inflammation in ovalbumin-induced asthma in mouse. Iran J Basic Med Sci 19(1):55-63

112. Chuang YC, Liou CW, Chen SD, Wang PW, Chuang JH, Tiao MM, Hsu TY, Lin HY, Lin TK (2017) Mitochondrial transfer from wharton's jelly mesenchymal stem cell to MERRF cybrid reduces oxidative stress and improves mitochondrial bioenergetics. Oxid Med Cell Longev. https://doi.org/10.1155/2017/56912 15

113. Fang SB, Zhang HY, Jiang AY, Fan XL, Lin YD, Li CL, Wang C, Meng XC, Fu QL (2018) Human iPSC-MSCs prevent steroid-resistant neutrophilic airway inflammation via modulating Th17 phenotypes. Stem Cell Res Ther 9(1):147. https://doi. org/10.1186/s13287-018-0897-y

114. Squillaro T, Peluso G, Galderisi U (2016) Clinical trials with mesenchymal stem cells: an update. Cell Transplant 25(5):829848. https://doi.org/10.3727/096368915X689622

115. Couto PS, Shatirishvili G, Bersenev A, Verter F (2019) First decade of clinical trials and published studies with mesenchymal stromal cells from umbilical cord tissue. Regen Med 14(4):309319. https://doi.org/10.2217/rme-2018-0171

116. Gugliandolo A, Bramanti P, Mazzon E (2019) mesenchymal stem cells: a potential therapeutic approach for amyotrophic lateral sclerosis? Stem Cells Int 2019:3675627. https://doi. org/10.1155/2019/3675627

117. Cho J, D'Antuono M, Glicksman M, Wang J, Jonklaas J (2018) A review of clinical trials: mesenchymal stem cell transplant therapy in type 1 and type 2 diabetes mellitus. Am J Stem Cells 7(4):82-93

118. Attwood SW, Edel MJ (2019) iPS-Cell technology and the problem of genetic instability-can it ever be safe for clinical use? J Clin Med 8(3):288. https://doi.org/10.3390/jcm8030288

119. Bhansali A, Upreti V, Khandelwal N, Marwaha N, Gupta V, Sachdeva N, Sharma RR, Saluja K, Dutta P, Walia R, Minz R, Bhadada S, Das S, Ramakrishnan S (2009) Efficacy of autologous bone marrow-derived stem cell transplantation in patients with type 2 diabetes mellitus. Stem Cells Dev 18(10):14071416. https://doi.org/10.1089/scd.2009.0164

120. Bhansali A, Asokumar P, Walia R, Bhansali S, Gupta V, Jain A, Sachdeva N, Sharma RR, Marwaha N, Khandelwal N (2014) Efficacy and safety of autologous bone marrow-derived stem cell transplantation in patients with type 2 diabetes mellitus: a randomized placebo-controlled study. Cell Transplant 23(9):1075-1085. https://doi.org/10.3727/096368913X665576

121. Jiang R, Han Z, Zhuo G, Qu X, Li X, Wang X, Shao Y, Yang $S$, Han ZC (2011) Transplantation of placenta-derived mesenchymal stem cells in type 2 diabetes: a pilot study. Front Med 5(1):94-100. https://doi.org/10.1007/s11684-011-0116-z

122. Jeon SR, Park JH, Lee JH, Kim DY, Kim HS, Sung IY, Choi GH, Jeon MH, Kim GG (2010) Treatment of spinal cord injury with bone marrow-derived, cultured autologous mesenchymal stem cells. Tissue Eng Regenerat Med 7(3):316-322

123. Sykova E, Homola A, Mazanec R, Lachmann H, Konradova SL, Kobylka P, Padr R, Neuwirth J, Komrska V, Vavra V, Stulik J, Bojar M (2006) Autologous bone marrow transplantation in patients with subacute and chronic spinal cord injury. Cell Transplant 15(8-9):675-687. https://doi.org/10.3727/00000 0006783464381

124. Pal R, Venkataramana NK, Jaan M, Bansal A, Balaraju S, Jaan M, Chandra R, Dixit A, Rauthan A, Murgod U, Totey S (2009) Ex vivo-expanded autologous bone marrow-derived mesenchymal stromal cells in human spinal cord injury/paraplegia: a pilot clinical study. Cytotherapy 11(7):897-911. https://doi. org/10.3109/14653240903253857
125. Karamouzian S, Nematollahi-Mahani SN, Nakhaee N, Eskandary H (2012) Clinical safety and primary efficacy of bone marrow mesenchymal cell transplantation in subacute spinal cord injured patients. Clin Neurol Neurosur 114(7):935939. https://doi.org/10.1016/j.clineuro.2012.02.003

126. Bhasin A, Srivastava MV, Kumaran SS, Mohanty S, Bhatia R, Bose S, Gaikwad S, Garg A, Airan B (2011) Autologous mesenchymal stem cells in chronic stroke. Cerebrovasc Dis Extra 1(1):93-104. https://doi.org/10.1159/000333381

127. Tsang KS, Ng CPS, Zhu XL, Wong GKC, Lu G, Ahuja AT, Wong KSL, Ng HK, Poon WS (2017) Phase I/II randomized controlled trial of autologous bone marrow-derived mesenchymal stem cell therapy for chronic stroke. World J Stem Cells 9(8):133-143. https://doi.org/10.4252/wjsc.v9.i8.133

128. Ahn SY, Chang YS, Sung SI, Park WS (2018) Mesenchymal stem cells for severe intraventricular hemorrhage in preterm infants: phase I dose-escalation clinical trial. Stem Cells Transl Med 7(12):847-856. https://doi.org/10.1002/sctm.17-0219

129. Liang X, Ding Y, Zhang Y, Tse HF, Lian Q (2014) Paracrine mechanisms of mesenchymal stem cell-based therapy: current status and perspectives. Cell Transplant 23(9):1045-1059. https://doi.org/10.3727/096368913X667709

130. Gnecchi M, He H, Liang OD, Melo LG, Morello F, Mu H, Noiseux N, Zhang L, Pratt RE, Ingwall JS, Dzau VJ (2005) Paracrine action accounts for marked protection of ischemic heart by Aktmodified mesenchymal stem cells. Nat Med 11(4):367-368. https ://doi.org/10.1038/nm0405-367

131. Cselenyak A, Pankotai E, Horvath EM, Kiss L, Lacza Z (2010) Mesenchymal stem cells rescue cardiomyoblasts from cell death in an in vitro ischemia model via direct cell-to-cell connections. BMC Cell Biol 11:29. https://doi.org/10.1186/1471-2121-11-29

132. Islam MN, Das SR, Emin MT, Wei M, Sun L, Westphalen K, Rowlands DJ, Quadri SK, Bhattacharya S, Bhattacharya J (2012) Mitochondrial transfer from bone-marrow-derived stromal cells to pulmonary alveoli protects against acute lung injury. Nat Med 18(5):759-765. https://doi.org/10.1038/nm.2736

133. Lee C, Mitsialis SA, Aslam M, Vitali SH, Vergadi E, Konstantinou G, Sdrimas K, Fernandez-Gonzalez A, Kourembanas S (2012) Exosomes mediate the cytoprotective action of mesenchymal stromal cells on hypoxia-induced pulmonary hypertension. Circulation 126(22):2601-2611. https://doi.org/10.1161/CIRCU LATIONAHA.112.114173

134. Zhang B, Yin Y, Lai RC, Tan SS, Choo AB, Lim SK (2014) Mesenchymal stem cells secrete immunologically active exosomes. Stem Cells Dev 23(11):1233-1244. https://doi.org/10.1089/ scd.2013.0479

135. Noth U, Osyczka AM, Tuli R, Hickok NJ, Danielson KG, Tuan RS (2002) Multilineage mesenchymal differentiation potential of human trabecular bone-derived cells. J Orthop Res 20(5):10601069. https://doi.org/10.1016/S0736-0266(02)00018-9

136. Fukumoto T, Sperling JW, Sanyal A, Fitzsimmons JS, Reinholz GG, Conover CA, O'Driscoll SW (2003) Combined effects of insulin-like growth factor-1 and transforming growth factor-beta1 on periosteal mesenchymal cells during chondrogenesis in vitro. Osteoarthr Cartilage 11(1):55-64

137. Satué M, Schüler C, Ginner N, Erben RG (2019) Intra-articularly injected mesenchymal stem cells promote cartilage regeneration, but do not permanently engraft in distant organs. Sci Rep 9(1):10153. https://doi.org/10.1038/s41598-019-46554-5

138. Joshi J, Abnavi MD, Kothapalli CR (2019) Synthesis and secretome release by human bone marrow mesenchymal stem cell spheroids within three-dimensional collagen hydrogels: Integrating experiments and modelling. J Tissue Eng Regen M 13(10):1923-1937. https://doi.org/10.1002/term.2943

139. Han J, Park J, Kim BS (2015) Integration of mesenchymal stem cells with nanobiomaterials for the repair of 
myocardial infarction. Adv Drug Deliv Rev 95:15-28. https:// doi.org/10.1016/j.addr.2015.09.002

140. Pijnappels DA, Schalij MJ, Ramkisoensing AA, van Tuyn J, de Vries AA, van der Laarse A, Ypey DL, Atsma DE (2008) Forced alignment of mesenchymal stem cells undergoing cardiomyogenic differentiation affects functional integration with cardiomyocyte cultures. Circ Res 103(2):167-176. https://doi. org/10.1161/CIRCRESAHA.108.176131

141. Popara J, Accomasso L, Vitale E, Gallina C, Roggio D, Iannuzzi A, Raimondo S, Rastaldo R, Alberto G, Catalano F, Martra G, Turinetto V, Pagliaro P, Giachino C (2018) Silica nanoparticles actively engage with mesenchymal stem cells in improving acute functional cardiac integration. Nanomedicine 13(10):1121-1138. https://doi.org/10.2217/nnm-2017-0309

142. Aurich H, Sgodda M, Kaltwasser P, Vetter M, Weise A, Liehr T, Brulport M, Hengstler JG, Dollinger MM, Fleig WE, Christ B (2009) Hepatocyte differentiation of mesenchymal stem cells from human adipose tissue in vitro promotes hepatic integration in vivo. Gut 58(4):570-581. https://doi.org/10.1136/ gut.2008.154880

143. Kuo TK, Hung SP, Chuang CH, Chen CT, Shih YRV, Fang SCY, Yang VW, Lee OK (2008) Stem cell therapy for liver disease: Parameters governing the success of using bone marrow mesenchymal stem cells. Gastroenterology 134(7):2111-2121. https:// doi.org/10.1053/j.gastro.2008.03.015

144. Joyce N, Annett G, Wirthlin L, Olson S, Bauer G, Nolta JA (2010) Mesenchymal stem cells for the treatment of neurodegenerative disease. Regen Med 5(6):933-946. https://doi. org/10.2217/rme.10.72

145. Tzameret A, Sher I, Belkin M, Treves AJ, Meir A, Nagler A, Levkovitch-Verbin H, Barshack I, Rosner M, Rotenstreich Y (2014) Transplantation of human bone marrow mesenchymal stem cells as a thin subretinal layer ameliorates retinal degeneration in a rat model of retinal dystrophy. Exp Eye Res 118:135-144. https:// doi.org/10.1016/j.exer.2013.10.023

146. Sottile F, Aulicino F, Theka I, Cosma MP (2016) Mesenchymal stem cells generate distinct functional hybrids in vitro via cell fusion or entosis. Sci Rep 6:36863. https://doi.org/10.1038/srep3 6863

147. Zhang LN, Kong CF, Zhao D, Cong XL, Wang SS, Ma L, Huang YH (2019) Fusion with mesenchymal stem cells differentially affects tumorigenic and metastatic abilities of lung cancer cells. J Cell Physiol 234(4):3570-3582. https://doi.org/10.1002/ jcp. 27011

148. Melzer C, von der Ohe J, Hass R (2019) In vivo cell fusion between mesenchymal stroma/stem-like cells and breast cancer cells. Cancers. https://doi.org/10.3390/cancers11020185

149. Bartholomew A, Sturgeon C, Siatskas M, Ferrer K, McIntosh K, Patil S, Hardy W, Devine S, Ucker D, Deans R, Moseley A, Hoffman R (2002) Mesenchymal stem cells suppress lymphocyte proliferation in vitro and prolong skin graft survival in vivo. Exp Hematol 30(1):42-48

150. Di Nicola M, Carlo-Stella C, Magni M, Milanesi M, Longoni PD, Matteucci P, Grisanti S, Gianni AM (2002) Human bone marrow stromal cells suppress T-lymphocyte proliferation induced by cellular or nonspecific mitogenic stimuli. Blood 99(10):3838-3843

151. Akiyama K, Chen C, Wang DD, Xu XT, Qu CY, Yamaza T, Cai T, Chen WJ, Sun LY, Shi ST (2012) Mesenchymal-stemcell-induced immunoregulation involves FAS-Ligand-/FASMediated T cell apoptosis. Cell Stem Cell 10(5):544-555. https ://doi.org/10.1016/j.stem.2012.03.007

152. Zhong H, Fan X-L, Fang S-B, Lin Y-D, Wen W, Fu Q-L (2019) Human pluripotent stem cell-derived mesenchymal stem cells prevent chronic allergic airway inflammation via TGF- $\beta 1$ Smad2/Smad3 signaling pathway in mice. Mol Immunol 109:5157. https://doi.org/10.1016/j.molimm.2019.02.017
153. Meisel R, Zibert A, Laryea M, Gobel U, Daubener W, Dilloo D (2004) Human bone marrow stromal cells inhibit allogeneic T-cell responses by indoleamine 2,3-dioxygenase-mediated tryptophan degradation. Blood 103(12):4619-4621. https://doi. org/10.1182/blood-2003-11-3909

154. Hwu P, Du MX, Lapointe R, Do M, Taylor MW, Young HA (2000) Indoleamine 2,3-dioxygenase production by human dendritic cells results in the inhibition of T cell proliferation. J Immunol 164(7):3596-3599

155. Sheng HM, Wang Y, Jin YQ, Zhang QY, Zhang Y, Wang L, Shen B, Yin S, Liu W, Cui L, Li NL (2008) A critical role of IFN gamma in priming MSC-mediated suppression of T cell proliferation through up-regulation of B7-H1. Cell Res 18(8):846-857. https://doi.org/10.1038/cr.2008.80

156. Aggarwal S, Pittenger MF (2005) Human mesenchymal stem cells modulate allogeneic immune cell responses. Blood 105(4):1815-1822. https://doi.org/10.1182/blood-2004-04-1559

157. Nemeth K, Leelahavanichkul A, Yuen PST, Mayer B, Parmelee A, Doi K, Robey PG, Leelahavanichkul K, Koller BH, Brown JM, Hu XZ, Jelinek I, Star RA, Mezey E (2009) Bone marrow stromal cells attenuate sepsis via prostaglandin E2dependent reprogramming of host macrophages to increase their interleukin 10 production. Nat Med 15 (1):42-49. doi:10.1038/ nm.1905.

158. Xu G, Zhang Y, Zhang L, Ren G, Shi Y (2007) The role of IL-6 in inhibition of lymphocyte apoptosis by mesenchymal stem cells. Biochem Biophys Res Commun 361(3):745-750. https ://doi.org/10.1016/j.bbrc.2007.07.052

159. Sato K, Ozaki K, Oh I, Meguro A, Hatanaka K, Nagai T, Muroi $\mathrm{K}$, Ozawa K (2007) Nitric oxide plays a critical role in suppression of T-cell proliferation by mesenchymal stem cells. Blood 109(1):228-234. https://doi.org/10.1182/blood-2006-02-00224 6

160. Nasef A, Mazurier C, Bouchet S, Francois S, Chapel A, Thierry D, Gorin NC, Fouillard L (2008) Leukemia inhibitory factor: role in human mesenchymal stem cells mediated immunosuppression. Cell Immunol 253(1-2):16-22. https://doi.org/10.1016/j. cellimm.2008.06.002

161. Lepelletier Y, Lecourt S, Renand A, Arnulf B, Vanneaux V, Fermand JP, Menasche P, Domet T, Marolleau JP, Hermine O, Larghero J (2010) Galectin-1 and semaphorin-3A are two soluble factors conferring T-cell immunosuppression to bone marrow mesenchymal stem cell. Stem Cells Dev 19(7):1075-1079. https ://doi.org/10.1089/scd.2009.0212

162. Di Ianni M, Del Papa B, De Ioanni M, Moretti L, Bonifacio E, Cecchini D, Sportoletti P, Falzetti F, Tabilio A (2008) Mesenchymal cells recruit and regulate T regulatory cells. Exp Hematol 36(3):309-318. https://doi.org/10.1016/j.exphem.2007.11.007

163. Tsyb AF, Petrov VN, Konoplyannikov AG, Saypina EV, Lepechina LA, Kalsina S, Semenkova IV, Agaeva EV (2008) In vitro inhibitory effect of mesenchymal stem cells on zymosan-induced production of reactive oxygen species. Bull Exp Biol Med 146(1):158-164

164. Jiang XX, Zhang Y, Liu B, Zhang SX, Wu Y, Yu XD, Mao N (2005) Human mesenchymal stem cells inhibit differentiation and function of monocyte-derived dendritic cells. Blood 105(10):4120-4126. https://doi.org/10.1182/blood -2004-02-0586

165. Oh JY, Lee RH, Yu JM, Ko JH, Lee HJ, Ko AY, Roddy GW, Prockop DJ (2012) Intravenous mesenchymal stem cells prevented rejection of allogeneic corneal transplants by aborting the early inflammatory response. Mol Ther 20(11):2143-2152. https://doi.org/10.1038/mt.2012.165

166. Zhang Y, Ge XH, Guo XJ, Guan SB, Li XM, Gu W, Xu WG (2017) Bone marrow mesenchymal stem cells inhibit the 
function of dendritic cells by secreting galectin-1. Biomed Res Int 2017:3248605. https://doi.org/10.1155/2017/3248605

167. Ding Y, Liang X, Zhang Y, Yi L, Shum HC, Chen Q, Chan BP, Fan H, Liu Z, Tergaonkar V, Qi Z, Tse HF, Lian Q (2018) Rap1 deficiency-provoked paracrine dysfunction impairs immunosuppressive potency of mesenchymal stem cells in allograft rejection of heart transplantation. Cell Death Dis 9(3):386. https://doi. org/10.1038/s41419-018-0414-3

168. He JG, Xie QL, Li BB, Zhou L, Yan D (2018) Exosomes derived from IDO1-overexpressing rat bone marrow mesenchymal stem cells promote immunotolerance of cardiac allografts. Cell Transplant. https://doi.org/10.1177/0963689718805375

169. Sivanathan KN, Gronthos S, Grey ST, Rojas-Canales D, Coates PT (2017) Immunodepletion and hypoxia preconditioning of mouse compact bone cells as a novel protocol to isolate highly immunosuppressive mesenchymal stem cells. Stem Cells Dev 26(7):512-527. https://doi.org/10.1089/scd.2016.0180

170. Killer MC, Nold P, Henkenius K, Fritz L, Riedlinger T, Barckhausen C, Frech M, Hackstein H, Neubauer A, Brendel C (2017) Immunosuppressive capacity of mesenchymal stem cells correlates with metabolic activity and can be enhanced by valproic acid. Stem Cell Res Ther 8(1):100. https://doi.org/10.1186/s1328 7-017-0553-y

171. Li W, Ren G, Huang Y, Su J, Han Y, Li J, Chen X, Cao K, Chen Q, Shou P, Zhang L, Yuan ZR, Roberts AL, Shi S, Le AD, Shi Y (2012) Mesenchymal stem cells: a double-edged sword in regulating immune responses. Cell Death Differ 19(9):1505-1513. https://doi.org/10.1038/cdd.2012.26

172. Cuerquis J, Romieu-Mourez R, François M, Routy J-P, Young YK, Zhao J, Eliopoulos N (2014) Human mesenchymal stromal cells transiently increase cytokine production by activated $\mathrm{T}$ cells before suppressing T-cell proliferation: effect of interferon- $\gamma$ and tumor necrosis factor- $\alpha$; stimulation. Cytotherapy 16(2):191202. https://doi.org/10.1016/j.jcyt.2013.11.008

173. Siekmann AF, Affolter M, Belting HG (2013) The tip cell concept 10 years after: new players tune in for a common theme. Exp Cell Res 319(9):1255-1263. https://doi.org/10.1016/j.yexcr 2013.01.019

174. Watt SM, Gullo F, van der Garde M, Markeson D, Camicia R, Khoo CP, Zwaginga JJ (2013) The angiogenic properties of mesenchymal stem/stromal cells and their therapeutic potential. Brit Med Bull 108(1):25-53. https://doi.org/10.1093/bmb/ldt031

175. Orlic D, Kajstura J, Chimenti S, Bodine DM, Leri A, Anversa $P$ (2003) Bone marrow stem cells regenerate infarcted myocardium. Pediatr Transplant 7:86-88. https://doi. org/10.1034/j.1399-3046.7.s3.13.x

176. Zhang B, Wu XD, Zhang X, Sun YX, Yan YM, Shi H, Zhu YH, Wu LJ, Pan ZJ, Zhu W, Qian H, Xu WR (2015) Human umbilical cord mesenchymal stem cell exosomes enhance angiogenesis through the Wnt4/beta-catenin pathway. Stem Cell Transl Med 4(5):513-522. https://doi.org/10.5966/sctm.2014-0267

177. Merino-Gonzalez C, Zuniga FA, Escudero C, Ormazabal V, Reyes C, Nova-Lamperti E, Salomon C, Aguayo C (2016) Mesenchymal stem cell-derived extracellular vesicles promote angiogenesis: potencial clinical application. Front Physiol. https://doi. org/10.3389/fphys.2016.00024

178. Kinnaird T, Stabile E, Burnett MS, Shou M, Lee CW, Barr S, Fuchs S, Epstein SE (2004) Local delivery of marrow-derived stromal cells augments collateral perfusion through paracrine mechanisms. Circulation 109(12):1543-1549. https://doi. org/10.1161/01.Cir.0000124062.31102.57

179. Hung SC, Pochampally RR, Chen SC, Hsu SC, Prockop DJ (2007) Angiogenic effects of human multipotent stromal cell conditioned medium activate the PI3K-Akt pathway in hypoxic endothelial cells to inhibit apoptosis, increase survival, and stimulate angiogenesis. Stem Cells 25(9):2363-2370. https:// doi.org/10.1634/stemcells.2006-0686

180. Kinnaird T, Stabile E, Burnett MS, Epstein SE (2004) Bone marrow-derived cells for enhancing collateral developmentMechanisms, animal data, and initial clinical experiences. Circ Res 95(4):354-363. https://doi.org/10.1161/01.Res.0000137878 .26174 .66

181. Zhang M, Mal N, Kiedrowski M, Chacko M, Askari AT, Popovic ZB, Koc ON, Penn MS (2007) SDF-1 expression by mesenchymal stem cells results in trophic support of cardiac myocytes after myocardial infarction. Faseb J 21(12):3197-3207. https:// doi.org/10.1096/fj.06-6558com

182. Ratushnyy A, Ezdakova M, Yakubets D, Buravkova L (2018) Angiogenic Activity of Human Adipose-Derived Mesenchymal Stem Cells Under Simulated Microgravity. Stem Cells Dev 27(12):831-837. https://doi.org/10.1089/scd.2017.0262

183. Bao L, Meng Q, Li Y, Deng S, Yu Z, Liu Z, Zhang L, Fan H (2017) C-Kit Positive cardiac stem cells and bone marrowderived mesenchymal stem cells synergistically enhance angiogenesis and improve cardiac function after myocardial infarction in a paracrine manner. J Cardiac Fail 23(5):403-415. https://doi. org/10.1016/j.cardfail.2017.03.002

184. Sanz L, Santos-Valle P, Alonso-Camino V, Salas C, Serrano A, Vicario JL, Cuesta AM, Compte M, Sanchez-Martin D, AlvarezVallina L (2008) Long-term in vivo imaging of human angiogenesis: critical role of bone marrow-derived mesenchymal stem cells for the generation of durable blood vessels. Microvasc Res 75(3):308-314. https://doi.org/10.1016/j.mvr.2007.11.007

185. Huang NF, Lam A, Fang Q, Sievers RE, Li S, Lee RJ (2009) Bone marrow-derived mesenchymal stem cells in fibrin augment angiogenesis in the chronically infarcted myocardium. Regen Med 4(4):527-538. https://doi.org/10.2217/rme.09.32

186. Sorrell JM, Baber MA, Caplan AI (2009) Influence of adult mesenchymal stem cells on in vitro vascular formation. Tissue Eng 15(7):1751-1761. https://doi.org/10.1089/ten.tea.2008.0254

187. Botto S, Streblow DN, DeFilippis V, White L, Kreklywich CN, Smith PP, Caposio P (2011) IL-6 in human cytomegalovirus secretome promotes angiogenesis and survival of endothelial cells through the stimulation of survivin. Blood 117(1):352-361. https://doi.org/10.1182/blood-2010-06-291245

188. Boomsma RA, Geenen DL (2012) Mesenchymal stem cells secrete multiple cytokines that promote angiogenesis and have contrasting effects on chemotaxis and apoptosis. PLoS ONE. https://doi.org/10.1371/journal.pone.0035685

189. Koch S, Tugues S, Li XJ, Gualandi L, Claesson-Welsh L (2011) Signal transduction by vascular endothelial growth factor receptors. Biochem J 437:169-183. https://doi.org/10.1042/Bj201 10301

190. Liang X, Ding Y, Lin F, Zhang Y, Zhou X, Meng Q, Lu X, Jiang G, Zhu H, Chen Y, Lian Q, Fan H, Liu Z (2019) Overexpression of ERBB4 rejuvenates aged mesenchymal stem cells and enhances angiogenesis via PI3K/AKT and MAPK/ERK pathways. Faseb J 33(3):4559-4570. https://doi.org/10.1096/fj.20180 1690R

191. Qian D, Gong J, He Z, Hua J, Lin S, Xu C, Meng H, Song Z (2015) Bone marrow-derived mesenchymal stem cells repair necrotic pancreatic tissue and promote angiogenesis by secreting cellular growth factors involved in the SDF-1 alpha / CXCR4 axis in rats. Stem Cells Int 2015:306836. https://doi. org/10.1155/2015/306836

192. Dong F, Harvey J, Finan A, Weber K, Agarwal U, Penn MS (2012) Myocardial CXCR4 expression is required for mesenchymal stem cell mediated repair following acute myocardial infarction. Circulation 126(3):314-324. https://doi.org/10.1161/ Circulationaha.111.082453 
193. Pasquet M, Golzio M, Mery E, Rafii A, Benabbou N, Mirshahi P, Hennebelle I, Bourin P, Allal B, Teissie J, Mirshahi M, Couderc B (2010) Hospicells (ascites-derived stromal cells) promote tumorigenicity and angiogenesis. Int J Cancer 126(9):2090-2101. https://doi.org/10.1002/ijc. 24886

194. Tao HY, Han ZB, Han ZC, Li ZJ (2016) Proangiogenic features of mesenchymal stem cells and their therapeutic applications. Stem Cells Int. https://doi.org/10.1155/2016/1314709

195. Zhou M, Liu Z, Liu C, Jiang XF, Wei ZQ, Qiao W, Ran F, Wang W, Qiao T, Liu CJ (2012) Tissue engineering of small-diameter vascular grafts by endothelial progenitor cells seeding heparincoated decellularized scaffolds. J Biomed Mater Res 100(1):111120. https://doi.org/10.1002/jbm.b.31928

196. Kaga T, Kawano H, Sakaguchi M, Nakazawa T, Taniyama Y, Morishita R (2012) Hepatocyte growth factor stimulated angiogenesis without inflammation: differential actions between hepatocyte growth factor, vascular endothelial growth factor and basic fibroblast growth factor. Vasc Pharmacol 57(1):3-9. https://doi. org/10.1016/j.vph.2012.02.002

197. Mirotsou M, Jayawardena TM, Schmeckpeper J, Gnecchi M, Dzau VJ (2011) Paracrine mechanisms of stem cell reparative and regenerative actions in the heart. J Mol Cell Cardiol 50(2):280-289. https://doi.org/10.1016/j.yjmcc.2010.08.005

198. Kwon S, Ki SM, Park SE, Kim MJ, Hyung B, Lee NK, Shim S, Choi BO, Na DL, Lee JE, Chang JW (2016) Anti-apoptotic effects of human Wharton's jelly-derived mesenchymal stem cells on skeletal muscle cells mediated via secretion of XCL1. Mol Ther 24(9):1550-1560. https://doi.org/10.1038/ mt.2016.125

199. Meirelles LD, Fontes AM, Covas DT, Caplan AI (2009) Mechanisms involved in the therapeutic properties of mesenchymal stem cells. Cytokine Growth F R 20(5-6):419-427. https://doi. org/10.1016/j.cytogfr.2009.10.002

200. Rehman J, Traktuev D, Li J, Merfeld-Clauss S, Temm-Grove CJ, Bovenkerk JE, Pell CL, Johnstone BH, Considine RV, March KL (2004) Secretion of angiogenic and antiapoptotic factors by human adipose stromal cells. Circulation 109(10):1292-1298. https://doi.org/10.1161/01.CIR.0000121425.42966.F1

201. Togel F, Weiss K, Yang Y, Hu Z, Zhang P, Westenfelder C (2007) Vasculotropic, paracrine actions of infused mesenchymal stem cells are important to the recovery from acute kidney injury. Am J Physiol Renal Physiol 292(5):F1626-1635. https://doi. org/10.1152/ajprenal.00339.2006

202. Okazaki T, Magaki T, Takeda M, Kajiwara Y, Hanaya R, Sugiyama K, Arita K, Nishimura M, Kato Y, Kurisu K (2008) Intravenous administration of bone marrow stromal cells increases survivin and Bcl-2 protein expression and improves sensorimotor function following ischemia in rats. Neurosci Lett 430(2):109114. https://doi.org/10.1016/j.neulet.2007.10.046

203. Wang SP, Wang ZH, Peng DY, Li SM, Wang H, Wang XH (2012) Therapeutic effect of mesenchymal stem cells in rats with intracerebral hemorrhage: reduced apoptosis and enhanced neuroprotection. Mol Med Rep 6(4):848-854. https://doi.org/10.3892/ mmr.2012.997

204. Oltvai ZN, Milliman CL, Korsmeyer SJ (1993) Bcl-2 heterodimerizes in vivo with a conserved homolog, Bax, that accelerates programmed cell death. Cell 74(4):609-619

205. Green DR, Reed JC (1998) Mitochondria and apoptosis. Science 281(5381):1309-1312

206. Tang YL, Zhao Q, Qin X, Shen L, Cheng L, Ge J, Phillips MI (2005) Paracrine action enhances the effects of autologous mesenchymal stem cell transplantation on vascular regeneration in rat model of myocardial infarction. Ann Thorac Surg 80(1):229_ 236. https://doi.org/10.1016/j.athoracsur.2005.02.072

207. Zhang Y, Yu S, Tuazon JP, Lee JY, Corey S, Kvederis L, Kingsbury C, Kaneko Y, Borlongan CV (2019) Neuroprotective effects of human bone marrow mesenchymal stem cells against cerebral ischemia are mediated in part by an anti-apoptotic mechanism. Neural Regen Res 14(4):597-604. https://doi.org/10.4103/16735374.247464

208. Pan GZ, Yang Y, Zhang J, Liu W, Wang GY, Zhang YC, Yang Q, Zhai FX, Tai Y, Liu JR, Zhang Q, Chen GH (2012) Bone marrow mesenchymal stem cells ameliorate hepatic ischemia/reperfusion injuries via inactivation of the MEK/ERK signaling pathway in rats. J Surg Res 178(2):935-948. https://doi.org/10.1016/j. jss.2012.04.070

209. Gerber HP, Dixit V, Ferrara N (1998) Vascular endothelial growth factor induces expression of the antiapoptotic proteins Bcl-2 and A1 in vascular endothelial cells. J Biol Chem 273(21):13313-13316

210. Kamarajan P, Bunek J, Lin Y, Nunez G, Kapila YL (2010) Receptor-interacting protein shuttles between cell death and survival signaling pathways. Mol Biol Cell 21(3):481-488. https:// doi.org/10.1091/mbc.E09-06-0530

211. Liu ZY, Ganju RK, Wang JF, Schweitzer K, Weksler B, Avraham S, Groopman JE (1997) Characterization of signal transduction pathways in human bone marrow endothelial cells. Blood 90(6):2253-2259

212. Redondo J, Sarkar P, Kemp K, Heesom KJ, Wilkins A, Scolding NJ, Rice CM (2018) Dysregulation of mesenchymal stromal cell antioxidant responses in progressive multiple sclerosis. Stem Cells Transl Med 7(10):748-758. https://doi.org/10.1002/ sctm.18-0045

213. Blaser H, Dostert C, Mak TW, Brenner D (2016) TNF and ROS crosstalk in inflammation. Trends Cell Biol 26(4):249-261. https ://doi.org/10.1016/j.tcb.2015.12.002

214. Russell EG, Cotter TG (2015) New insight into the role of reactive oxygen species (ROS) in cellular signal-transduction processes. Int Rev Cel Mol Bio 319:221-254. https://doi. org/10.1016/bs.ircmb.2015.07.004

215. Kreuz S, Fischle W (2016) Oxidative stress signaling to chromatin in health and disease. Epigenomics 8(6):843-862. https://doi. org/10.2217/epi-2016-0002

216. Ohkouchi S, Block GJ, Katsha AM, Kanehira M, Ebina M, Kikuchi T, Saijo Y, Nukiwa T, Prockop DJ (2012) Mesenchymal stromal cells protect cancer cells from ROS-induced apoptosis and enhance the Warburg effect by secreting STC1. Mol Ther 20(2):417-423. https://doi.org/10.1038/mt.2011.259

217. Li J, Li D, Liu X, Tang S, Wei F (2012) Human umbilical cord mesenchymal stem cells reduce systemic inflammation and attenuate LPS-induced acute lung injury in rats. J Inflamm 9(1):33. https://doi.org/10.1186/1476-9255-9-33

218. Whone AL, Kemp K, Sun M, Wilkins A, Scolding NJ (2012) Human bone marrow mesenchymal stem cells protect catecholaminergic and serotonergic neuronal perikarya and transporter function from oxidative stress by the secretion of glialderived neurotrophic factor. Brain Res 1431:86-96. https://doi. org/10.1016/j.brainres.2011.10.038

219. Liu DJ, Huang LP, Wang YL, Wang W, Wehrens XHT, Belousova T, Abdelrahim M, DiMattia G, Sheikh-Hamad D (2012) Human stanniocalcin-1 suppresses angiotensin II-induced superoxide generation in cardiomyocytes through UCP3-mediated anti-oxidant pathway. PLoS ONE. https://doi.org/10.1371/journ al.pone.0036994

220. Ono M, Ohkouchi S, Kanehira M, Tode N, Kobayashi M, Ebina M, Nukiwa T, Irokawa T, Ogawa H, Akaike T, Okada Y, Kurosawa H, Kikuchi T, Ichinose M (2015) Mesenchymal stem cells correct inappropriate epithelial-mesenchyme relation in pulmonary fibrosis using stanniocalcin-1. Mol Ther 23(3):549-560. https://doi.org/10.1038/mt.2014.217

221. Ono M, Ohkouchi S, Kanehira M, Tode N, Kikuchi T, Ichinose M (2014) The Enhancement Of Stanniocalcin-1 (STC1) 
Secretion Increases The Ability Of Mesenchymal Stem Cells (MSCs) Reducing Bleomycin-Induced Lung Fibrosis In Mice Model Through Inhibition Of ROS/Endoplasmic Reticulum Stress (ER-Stress)/TGF?1 Pathway. In: C108. IS THERE ANYTHING THEY CAN'T DO? DIVERSE FUNCTIONAL ACTIVITIES OF MESENCHYMAL STEM AND STROMAL CELLS. American Thoracic Society International Conference Abstracts. American Thoracic Society, pp A5305-A5305. doi:10.1164/ ajrccm-conference.2014.189.1_MeetingAbstracts.A5305

222. Oh JY, Ko JH, Lee HJ, Yu JM, Choi H, Kim MK, Wee WR, Prockop DJ (2014) Mesenchymal stem/stromal cells inhibit the NLRP3 inflammasome by decreasing mitochondrial reactive oxygen species. Stem Cells 32(6):1553-1563. https://doi. org/10.1002/stem.1608

223. Chen XX, Zhang YL, Wang WJ, Liu ZQ, Meng JG, Han ZH (2018) Mesenchymal stem cells modified with heme oxygenase-1 have enhanced paracrine function and attenuate lipopolysaccharide-induced inflammatory and oxidative damage in pulmonary microvascular endothelial cells. Cell Physiol Biochem 49(1):101-122. https://doi.org/10.1159/000492847

224. Zhang ZH, Zhu W, Ren HZ, Zhao X, Wang S, Ma HC, Shi XL (2017) Mesenchymal stem cells increase expression of heme oxygenase-1 leading to anti-inflammatory activity in treatment of acute liver failure. Stem Cell Res Ther 8(1):70. https://doi. org/10.1186/s13287-017-0524-3

225. Yu J, Li MC, Qu ZL, Yan D, Li DJ, Ruan QR (2010) SDF-1/ CXCR4-Mediated migration of transplanted bone marrow stromal cells toward areas of heart myocardial infarction through activation of PI3K/Akt. J Cardiovasc Pharm 55(5):496-505. https ://doi.org/10.1097/FJC.0b013e3181d7a384

226. Hoban DB, Howard L, Dowd E (2015) Gdnf-secreting mesenchymal stem cells provide localized neuroprotection in an inflammation-driven rat model of Parkinson's Disease. Neuroscience 303:402-411. https://doi.org/10.1016/j.neuroscien ce.2015.07.014

227. Lv BK, Li F, Fang J, Xu LM, Sun CM, Han JB, Hua T, Zhang ZF, Feng ZM, Wang QH, Jiang XD (2016) Activated microglia induce bone marrow mesenchymal stem cells to produce glial cell-derived neurotrophic factor and protect neurons against oxygen-glucose deprivation injury. Front Cell Neurosci. https:// doi.org/10.3389/fncel.2016.00283

228. Consentius C, Reinke P, Volk HD (2015) Immunogenicity of allogeneic mesenchymal stromal cells: what has been seen in vitro and in vivo? Regen Med 10(3):305-315. https://doi. org/10.2217/Rme.15.14

229. Sivanathan KN, Gronthos S, Rojas-Canales D, Thierry B, Coates PT (2014) Interferon-gamma modification of mesenchymal stem cells: implications of autologous and allogeneic mesenchymal stem cell therapy in allotransplantation. Stem Cell Rev 10(3):351-375. https://doi.org/10.1007/s12015-014-9495-2

230. Duffy MM, Pindjakova J, Hanley SA, McCarthy C, Weidhofer GA, Sweeney EM, English K, Shaw G, Murphy JM, Barry FP, Mahon BP, Belton O, Ceredig R, Griffin MD (2011) Mesenchymal stem cell inhibition of T-helper 17 cell- differentiation is triggered by cell-cell contact and mediated by prostaglandin E2 via the EP4 receptor. Eur J Immunol 41(10):2840-2851. https:// doi.org/10.1002/eji.201141499

231. Kovach TK, Dighe AS, Lobo PI, Cui Q (2015) Interactions between MSCs and immune cells: implications for bone healing. J Immunol Res 2015:752510. https://doi.org/10.1155/2015/75251 0

232. Luz-Crawford P, Noel D, Fernandez X, Khoury M, Figueroa F, Carrion F, Jorgensen C, Djouad F (2012) Mesenchymal stem cells repress Th17 molecular program through the PD-1 pathway. PLoS ONE. https://doi.org/10.1371/journal.pone.0045272
233. Sioud M, Mobergslien A, Boudabous A, Floisand Y (2011) Mesenchymal stem cell-mediated T cell suppression occurs through secreted galectins. Int J Oncol 38(2):385-390. https:// doi.org/10.3892/ijo.2010.869

234. English K, Ryan JM, Tobin L, Murphy MJ, Barry FP, Mahon BP (2009) Cell contact, prostaglandin E(2) and transforming growth factor beta 1 play non-redundant roles in human mesenchymal stem cell induction of CD4+CD25(High) forkhead box P3+ regulatory T cells. Clin Exp Immunol 156(1):149-160. https:// doi.org/10.1111/j.1365-2249.2009.03874.x

235. Casado JG, Tarazona R, Sanchez-Margallo FM (2013) NK and MSCs crosstalk: The sense of immunomodulation and their sensitivity. Stem Cell Rev Rep 9(2):184-189. https://doi. org/10.1007/s12015-013-9430-y

236. Chatterjee D, Tufa DM, Baehre H, Hass R, Schmidt RE, Jacobs R (2014) Natural killer cells acquire CD73 expression upon exposure to mesenchymal stem cells. Blood 123(4):594-595. https:// doi.org/10.1182/blood-2013-09-524827

237. Li Y, Zhang D, Xu L, Dong L, Zheng J, Lin Y, Huang J, Zhang Y, Tao Y, Zang X, Li D, Du M (2019) Cell-cell contact with proinflammatory macrophages enhances the immunotherapeutic effect of mesenchymal stem cells in two abortion models. Cell Mol Immunol. https://doi.org/10.1038/s41423-019-0204-6

238. Zhang B, Liu R, Shi D, Liu XX, Chen Y, Dou XW, Zhu XS, Lu CH, Liang W, Liao LM, Zenke M, Zhao RCH (2009) Mesenchymal stem cells induce mature dendritic cells into a novel Jagged-2-dependent regulatory dendritic cell population. Blood 113(1):46-57. https://doi.org/10.1182/blood-2008-04154138

239. Loibl M, Binder A, Herrmann M, Duttenhoefer F, Richards RG, Nerlich M, Alini M, Verrier S (2014) Direct cell-cell contact between mesenchymal stem cells and endothelial progenitor cells induces a pericyte-like phenotype in vitro. Biomed Res Int. https ://doi.org/10.1155/2014/395781

240. Menge T, Gerber M, Wataha K, Reid W, Guha S, Cox CS, Dash P, Reitz MS, Khakoo AY, Pati S (2013) Human mesenchymal stem cells inhibit endothelial proliferation and angiogenesis via cell-cell contact through modulation of the VE-Cadherin/betaCatenin signaling pathway. Stem Cells Dev 22(1):148-157. https ://doi.org/10.1089/scd.2012.0165

241. Paliwal S, Chaudhuri R, Agrawal A, Mohanty S (2018) Regenerative abilities of mesenchymal stem cells through mitochondrial transfer. J Biomed Sci 25(1):31-31. https://doi.org/10.1186/ s12929-018-0429-1

242. Babenko VA, Silachev DN, Popkov VA, Zorova LD, Pevzner IB, Plotnikov EY, Sukhikh GT, Zorov DB (2018) Miro1 enhances mitochondria transfer from multipotent mesenchymal stem cells (MMSC) to neural cells and improves the efficacy of cell recovery. Molecules. https://doi.org/10.3390/molecules23030687

243. Torralba D, Baixauli F, Sanchez-Madrid F (2016) Mitochondria know no boundaries: mechanisms and functions of intercellular mitochondrial transfer. Front Cell Dev Biol 4:107. https://doi. org/10.3389/fcell.2016.00107

244. Sinha P, Islam MN, Bhattacharya S, Bhattacharya J (2016) Intercellular mitochondrial transfer: bioenergetic crosstalk between cells. Curr Opin Genet Dev 38:97-101. https://doi.org/10.1016/j. gde.2016.05.002

245. Feng Y, Zhu R, Shen J, Wu J, Lu W, Zhang J, Zhang J, Liu K (2019) Human bone marrow mesenchymal stem cells rescue endothelial cells experiencing chemotherapy stress by mitochondrial transfer via tunneling nanotubes. Stem Cells Dev 28(10):674-682. https://doi.org/10.1089/scd.2018.0248

246. Wanet A, Remacle N, Najar M, Sokal E, Arnould T, Najimi M, Renard P (2014) Mitochondrial remodeling in hepatic differentiation and dedifferentiation. Int J Biochem Cell Biol 54:174-185. https://doi.org/10.1016/j.biocel.2014.07.015 
247. Youle RJ, Narendra DP (2011) Mechanisms of mitophagy. Nat Rev Mol Cell Biol 12(1):9-14. https://doi.org/10.1038/nrm3028

248. Boukelmoune N, Chiu GS, Kavelaars A, Heijnen CJ (2018) Mitochondrial transfer from mesenchymal stem cells to neural stem cells protects against the neurotoxic effects of cisplatin. Acta Neuropathol Commun 6(1):139. https://doi.org/10.1186/s4047 8-018-0644-8

249. Watkins J, Basu S, Bogenhagen DF (2008) A quantitative proteomic analysis of mitochondrial participation in p19 cell neuronal differentiation. J Proteome Res 7(1):328-338. https://doi. org/10.1021/pr070300g

250. Ding WX, Yin XM (2012) Mitophagy: mechanisms, pathophysiological roles, and analysis. Biol Chem 393(7):547-564. https:// doi.org/10.1515/hsz-2012-0119

251. Jiang D, Gao F, Zhang Y, Wong DS, Li Q, Tse HF, Xu G, Yu Z, Lian Q (2016) Mitochondrial transfer of mesenchymal stem cells effectively protects corneal epithelial cells from mitochondrial damage. Cell Death Dis 7(11):e2467. https://doi.org/10.1038/ cddis. 2016.358

252. Jiang D, Xiong GY, Feng H, Zhang Z, Chen PK, Yan B, Chen L, Gandhervin K, Ma CY, Li C, Han S, Zhang YL, Liao C, Lee TL, Tse HF, Fu QL, Chiu K, Lian QZ (2019) Donation of mitochondria by iPSC-derived mesenchymal stem cells protects retinal ganglion cells against mitochondrial complex I defectinduced degeneration. Theranostics 9(8):2395-2410. https://doi. org/10.7150/thno.29422

253. Li H, Wang C, He T, Zhao T, Chen YY, Shen YL, Zhang X, Wang LL (2019) Mitochondrial transfer from bone marrow mesenchymal stem cells to motor neurons in spinal cord injury rats via gap junction. Theranostics 9(7):2017-2035. https://doi. org/10.7150/thno. 29400

254. Ahmad T, Mukherjee S, Pattnaik BR, Kumar M, Singh S, Rehman R, Kumar M, Jha A, Wani M, Mabalirajan U, Ghosh B, Sinha Roy S, Agrawal A (2013) Miro 1 knockdown in stem cells inhibits mitochondrial donation mediated rescue of bronchial epithelial injury. Biophys J 104(2):659a. https://doi.org/10.1016/j. bpj.2012.11.3638

255. Ahmad T, Mukherjee S, Pattnaik B, Kumar M, Singh S, Kumar M, Rehman R, Tiwari BK, Jha KA, Barhanpurkar AP, Wani MR, Roy SS, Mabalirajan U, Ghosh B, Agrawal A (2014) Miro1 regulates intercellular mitochondrial transport \& enhances mesenchymal stem cell rescue efficacy. Embo J 33(9):994-1010. https:// doi.org/10.1002/embj.201386030

256. Zhang Y, Yu Z, Jiang D, Liang X, Liao S, Zhang Z, Yue W, Li X, Chiu SM, Chai YH, Liang Y, Chow Y, Han S, Xu A, Tse HF, Lian Q (2016) iPSC-MSCs with high intrinsic MIRO1 and sensitivity to TNF-alpha yield efficacious mitochondrial transfer to rescue anthracycline-induced cardiomyopathy. Stem Cell Reports 7(4):749-763. https://doi.org/10.1016/j.stemcr.2016.08.009

257. Pacak CA, Preble JM, Kondo H, Seibel P, Levitsky S, Del Nido PJ, Cowan DB, McCully JD (2015) Actin-dependent mitochondrial internalization in cardiomyocytes: evidence for rescue of mitochondrial function. Biol Open 4(5):622-626. https://doi. org/10.1242/bio.201511478

258. Sinclair KA, Yerkovich ST, Hopkins PM, Chambers DC (2016) Characterization of intercellular communication and mitochondrial donation by mesenchymal stromal cells derived from the human lung. Stem Cell Res Ther 7(1):91. https://doi.org/10.1186/ s13287-016-0354-8

259. Morrison TJ, Jackson MV, Cunningham EK, Kissenpfennig A, McAuley DF, O'Kane CM, Krasnodembskaya AD (2017) Mesenchymal stromal cells modulate macrophages in clinically relevant lung injury models by extracellular vesicle mitochondrial transfer. Am J Respir Crit Care Med 196(10):1275-1286. https ://doi.org/10.1164/rccm.201701-0170OC
260. Dostert G, Mesure B, Menu P, Velot É (2017) How do mesenchymal stem cells influence or are influenced by microenvironment through extracellular vesicles communication? Front Cell Dev Biol 5:6-6. https://doi.org/10.3389/fcell.2017.00006

261. Raposo G, Stoorvogel W (2013) Extracellular vesicles: exosomes, microvesicles, and friends. J Cell Biol 200(4):373383. https://doi.org/10.1083/jcb.201211138

262. Lai RC, Tan SS, Yeo RWY, Choo ABH, Reiner AT, Su Y, Shen Y, Fu Z, Alexander L, Sze SK, Lim SK (2016) MSC secretes at least $3 \mathrm{EV}$ types each with a unique permutation of membrane lipid, protein and RNA. J Extracell Ves 5:29828-29828. https:// doi.org/10.3402/jev.v5.29828

263. Li Y, Cheng Q, Hu G, Deng T, Wang Q, Zhou J, Su X (2018) Extracellular vesicles in mesenchymal stromal cells: A novel therapeutic strategy for stroke. Exp Ther Med 15(5):4067-4079. https://doi.org/10.3892/etm.2018.5993

264. Konala VB, Mamidi MK, Bhonde R, Das AK, Pochampally R, Pal R (2016) The current landscape of the mesenchymal stromal cell secretome: A new paradigm for cell-free regeneration. Cytotherapy 18(1):13-24. https://doi.org/10.1016/j.jcyt.2015.10.008

265. Galieva LR, James V, Mukhamedshina YO, Rizvanov AA (2019) Therapeutic potential of extracellular vesicles for the treatment of nerve disorders. Front Neurosci 13:163. https://doi.org/10.3389/ fnins.2019.00163

266. Montemurro T, Vigano M, Ragni E, Barilani M, Parazzi V, Boldrin V, Lavazza C, Montelatici E, Banfi F, Lauri E, Giovanelli S, Baccarin M, Guerneri S, Giordano R, Lazzari L (2016) Angiogenic and anti-inflammatory properties of mesenchymal stem cells from cord blood: soluble factors and extracellular vesicles for cell regeneration. Eur J Cell Biol 95(6-7):228-238. https:// doi.org/10.1016/j.ejcb.2016.04.003

267. Anderson JD, Johansson HJ, Graham CS, Vesterlund M, Pham MT, Bramlett CS, Montgomery EN, Mellema MS, Bardini RL, Contreras Z, Hoon M, Bauer G, Fink KD, Fury B, Hendrix KJ, Chedin F, El-Andaloussi S, Hwang B, Mulligan MS, Lehtio J, Nolta JA (2016) Comprehensive proteomic analysis of mesenchymal stem cell exosomes reveals modulation of angiogenesis via nuclear factor-KappaB signaling. Stem Cells 34(3):601-613. https://doi.org/10.1002/stem.2298

268. Nakamura Y, Miyaki S, Ishitobi H, Matsuyama S, Nakasa T, Kamei N, Akimoto T, Higashi Y, Ochi M (2015) Mesenchymalstem-cell-derived exosomes accelerate skeletal muscle regeneration. Febs Lett 589(11):1257-1265. https://doi.org/10.1016/j. febslet.2015.03.031

269. Feng YL, Huang W, Wani M, Yu XY, Ashraf M (2014) Ischemic Preconditioning potentiates the protective effect of stem cells through secretion of exosomes by targeting Mecp2 via miR-22. PLoS ONE. https://doi.org/10.1371/journal.pone.0088685

270. Wang X, Gu H, Qin D, Yang L, Huang W, Essandoh K, Wang Y, Caldwell CC, Peng T, Zingarelli B, Fan GC (2015) Exosomal miR-223 contributes to mesenchymal stem cell-elicited cardioprotection in polymicrobial sepsis. Sci Rep 5:13721. https://doi. org/10.1038/srep13721

271. Song Y, Dou H, Li X, Zhao X, Li Y, Liu D, Ji J, Liu F, Ding L, Ni Y, Hou Y (2017) Exosomal miR-146a contributes to the enhanced therapeutic efficacy of interleukin-1beta-primed mesenchymal stem cells against sepsis. Stem Cells 35(5):1208-1221. https://doi.org/10.1002/stem.2564

272. Fang S, Xu C, Zhang Y, Xue C, Yang C, Bi H, Qian X, Wu M, Ji K, Zhao Y, Wang Y, Liu H, Xing X (2016) Umbilical cordderived mesenchymal stem cell-derived exosomal micrornas suppress myofibroblast differentiation by inhibiting the transforming growth factor-beta/SMAD2 pathway during wound healing. Stem Cells Transl Med 5(10):1425-1439. https://doi.org/10.5966/ sctm.2015-0367 
273. Tomasoni S, Longaretti L, Rota C, Morigi M, Conti S, Gotti E, Capelli C, Introna M, Remuzzi G, Benigni A (2013) Transfer of growth factor receptor mRNA via exosomes unravels the regenerative effect of mesenchymal stem cells. Stem Cells Dev 22(5):772-780. https://doi.org/10.1089/scd.2012.0266

274. Zhu LP, Tian T, Wang JY, He JN, Chen T, Pan M, Xu L, Zhang HX, Qiu XT, Li CC, Wang KK, Shen H, Zhang GG, Bai YP (2018) Hypoxia-elicited mesenchymal stem cell-derived exosomes facilitates cardiac repair through miR-125b-mediated prevention of cell death in myocardial infarction. Theranostics 8(22):6163-6177. https://doi.org/10.7150/thno.28021

275. Gong XH, Liu H, Wang SJ, Liang SW, Wang GG (2019) Exosomes derived from SDF1-overexpressing mesenchymal stem cells inhibit ischemic myocardial cell apoptosis and promote cardiac endothelial microvascular regeneration in mice with myocardial infarction. J Cell Physiol 234(8):13878-13893. https ://doi.org/10.1002/jcp.28070

276. Khare D, Or R, Resnick I, Barkatz C, Almogi-Hazan O, Avni B (2018) Mesenchymal stromal cell-derived exosomes affect mRNA expression and function of B-lymphocytes. Front Immunol 9:3053. https://doi.org/10.3389/fimmu.2018.03053

277. Di Trapani M, Bassi G, Midolo M, Gatti A, Kamga PT, Cassaro A, Carusone R, Adamo A, Krampera M (2016) Differential and transferable modulatory effects of mesenchymal stromal cellderived extracellular vesicles on T, B and NK cell functions. Sci Rep 6:24120. https://doi.org/10.1038/srep24120

278. Del Fattore A, Luciano R, Pascucci L, Goffredo BM, Giorda E, Scapaticci M, Fierabracci A, Muraca M (2015) Immunoregulatory effects of mesenchymal stem cell-derived extracellular vesicles on T Lymphocytes. Cell Transplant 24(12):2615-2627. https://doi.org/10.3727/096368915X687543

279. Kerkela E, Laitinen A, Rabina J, Valkonen S, Takatalo M, Larjo A, Veijola J, Lampinen M, Siljander P, Lehenkari P, Alfthan K, Laitinen S (2016) Adenosinergic immunosuppression by human mesenchymal stromal cells requires co-operation with $\mathrm{T}$ cells. Stem Cells 34(3):781-790. https://doi.org/10.1002/stem.2280

280. Pakravan K, Babashah S, Sadeghizadeh M, Mowla SJ, Mossahebi-Mohammadi M, Ataei F, Dana N, Javan M (2017) MicroRNA-100 shuttled by mesenchymal stem cell-derived exosomes suppresses in vitro angiogenesis through modulating the mTOR/HIF-1alpha/VEGF signaling axis in breast cancer cells. Cell Oncol 40(5):457-470. https://doi.org/10.1007/s1340 2-017-0335-7

281. Lopatina T, Gai C, Deregibus MC, Kholia S, Camussi G (2016) Cross Talk between cancer and mesenchymal stem cells through extracellular vesicles carrying nucleic acids. Front Oncol 6:125. https://doi.org/10.3389/fonc.2016.00125

282. Whiteside TL (2018) Exosome and mesenchymal stem cell crosstalk in the tumor microenvironment. Semin Immunol 35:69-79. https://doi.org/10.1016/j.smim.2017.12.003

283. Yang Y, Bucan V, Baehre H, von der Ohe J, Otte A, Hass R (2015) Acquisition of new tumor cell properties by MSC-derived exosomes. Int J Oncol 47(1):244-252. https://doi.org/10.3892/ ijo.2015.3001

284. Zhou J, Tan X, Tan Y, Li Q, Ma J, Wang G (2018) Mesenchymal stem cell derived exosomes in cancer progression, metastasis and drug delivery: a comprehensive review. J Cancer 9(17):31293137. https://doi.org/10.7150/jca.25376

285. Carty F, Mahon BP, English K (2017) The influence of macrophages on mesenchymal stromal cell therapy: passive or aggressive agents? Clin Exp Immunol 188(1):1-11. https://doi. org/10.1111/cei.12929

286. Engela AU, Baan CC, Peeters AMA, Weimar W, Hoogduijn MJ (2013) Interaction between adipose tissue-derived mesenchymal stem cells and regulatory T-Cells. Cell Transplant 22(1):41-54. https://doi.org/10.3727/096368912x636984

287. Ayala-Cuellar AP, Kang JH, Jeung EB, Choi KC (2019) Roles of mesenchymal stem cells in tissue regeneration and immunomodulation. Biomol Ther 27(1):25-33. https://doi.org/10.4062/biomo lther.2017.260

288. Braza F, Dirou S, Forest V, Sauzeau V, Hassoun D, Chesne J, Cheminant-Muller MA, Sagan C, Magnan A, Lemarchand P (2016) Mesenchymal stem cells induce suppressive macrophages through phagocytosis in a mouse model of asthma. Stem Cells 34(7):1836-1845. https://doi.org/10.1002/stem.2344

289. Ferreira JR, Teixeira GQ, Santos SG, Barbosa MA, AlmeidaPorada G, Goncalves RM (2018) Mesenchymal stromal cell secretome: influencing therapeutic potential by cellular preconditioning. Front Immunol 9:2837. https://doi.org/10.3389/ fimmu.2018.02837

290. Zimmermann JA, Hettiaratchi MH, McDevitt TC (2017) Enhanced immunosuppression of T cells by sustained presentation of bioactive interferon-gamma within three-dimensional mesenchymal stem cell constructs. Stem Cell Transl Med 6(1):223-237. https://doi.org/10.5966/sctm.2016-0044

291. Bartosh TJ, Ylostalo JH, Mohammadipoor A, Bazhanov N, Coble K, Claypool K, Lee RH, Choi H, Prockop DJ (2010) Aggregation of human mesenchymal stromal cells (MSCs) into 3D spheroids enhances their antiinflammatory properties. P Natl Acad Sci USA 107(31):13724-13729. https://doi.org/10.1073/pnas.10081 17107

292. Mao AS, Ozkale B, Shah NJ, Vining KH, Descombes T, Zhang LY, Tringides CM, Wong SW, Shin JW, Scadden DT, Weitz DA, Mooney DJ (2019) Programmable microencapsulation for enhanced mesenchymal stem cell persistence and immunomodulation. P Natl Acad Sci USA 116(31):15392-15397. https://doi. org/10.1073/pnas.1819415116

Publisher's Note Springer Nature remains neutral with regard to jurisdictional claims in published maps and institutional affiliations. 